\title{
OPEN Mild hyperthermia induced by gold nanorods acts as a dual-edge blade in the fate of SH-SY5Y cells via autophagy
}

\author{
Maryam Ghafarkhani ${ }^{1}$, Cigir Biray Avci $^{2}$, Reza Rahbarghazi ${ }^{3,4}$, Abbas Karimi $^{5}$, \\ Majid Sadeghizadeh ${ }^{6}$, Amir Zarebkohan ${ }^{1,4} \bowtie$ Farhad Bani $^{1,4} \bowtie$
}

Unraveling unwanted side effects of nanotechnology-based therapies like photothermal therapy (PTT) is vital in translational nanomedicine. Herein, we monitored the relationship between autophagic response at the transcriptional level by using a PCR array and tumor formation ability by colony formation assay in the human neuroblastoma cell line, SH-SY5Y, $48 \mathrm{~h}$ after being exposed to two different mild hyperthermia $\left(43\right.$ and $48^{\circ} \mathrm{C}$ ) induced by PTT. In this regard, the promotion of apoptosis and autophagy were evaluated using immunofluorescence imaging and flow cytometry analyses. Protein levels of Ki-67, P62, and LC3 were measured using ELISA. Our results showed that of 86 genes associated with autophagy, the expression of 54 genes was changed in response to PTT. Also, we showed that chaperone-mediated autophagy (CMA) and macroautophagy are stimulated in PTT. Importantly, the results of this study also showed significant changes in genes related to the crosstalk between autophagy, dormancy, and metastatic activity of treated cells. Our findings illustrated that PTT enhances the aggressiveness of cancer cells at $43^{\circ} \mathrm{C}$, in contrast to $48^{\circ} \mathrm{C}$ by the regulation of autophagy-dependent manner.

Nano-bio interactions and biological consequences of using nanotechnology-based therapies have been considered a hot topic in the recent decay because of its importance in the bench to bedside translation. Considering various advantages such as noninvasive entity, short treatment schedule, lower side effects to healthy cells, and high efficiency compared to chemo/radiotherapy, PTT has attracted immense interest in cancer therapy ${ }^{1-3}$. PTT can selectively increase the intracellular and/or tumor niche temperature to the range of $40-80^{\circ} \mathrm{C}$. These features alter and destroy cell membrane-bounded proteins, cellular skeleton scaffold, and subcellular organelles, thereby leading to tumor cell degeneration and attrition ${ }^{4}$.

On the other hand, it was confirmed that cancer cells could evade chemotherapeutic agents and therapeutic strategies by engaging biological mechanisms like autophagy ${ }^{5-8}$. Autophagy is a multistep lysosomal degradation pathway that mediating the removal of damaged cellular entities in response to various insults ${ }^{9-11}$. Importantly, autophagy promotion is completely associated with the intensity of stress plays a dual role in cancer fate, as promoter or suppressor ${ }^{12-15}$. So, modulation of autophagic response is considered a promising strategy to improve cancer therapy in clinical trials ${ }^{13,16}$.

Regarding the significant impact of stress on tumor dynamic growth and expansion, it is important to know which kind of cell death mechanisms will occur inside the cancer niche post-PTT ${ }^{5}$. For example, sudden release of large amounts of growth/proinflammatory factors following necrotic death increases the risk of exacerbating the aggressiveness and metastatic capability of the remaining cancer cells ${ }^{5,17}$. Commensurate with these comments, researchers have focused on mild hyperthermia $\left(43-48^{\circ} \mathrm{C}\right)$ induced by PTT, to avoid such risks ${ }^{18-20}$.

To our knowledge, the exact and close relationship between tumor cell death type induced by PTT and tumorigenesis capability of cancer cells has not yet been completely addressed ${ }^{17,21}$. More recently, Yujuan and

\footnotetext{
${ }^{1}$ Department of Medical Nanotechnology, Faculty of Advanced Medical Sciences, Tabriz University of Medical Sciences, 516661-4733 Tabriz, Iran. ${ }^{2}$ Department of Medical Biology, Medical Faculty, Ege University, Bornova, 35100 Izmir, Turkey. ${ }^{3}$ Department of Applied Cell Sciences, Faculty of Advanced Medical Sciences, Tabriz University of Medical Sciences, Tabriz, Iran. ${ }^{4}$ Stem Cell Research Center, Tabriz University of Medical Sciences, Tabriz, Iran. ${ }^{5}$ Department of Molecular Medicine, Faculty of Advanced Medical Sciences, Tabriz University of Medical Sciences, Tabriz, Iran. ${ }^{6}$ Department of Nanobiotechnology, Faculty of Medical Sciences, Tarbiat Modares University, Tehran, Iran. ${ }^{\bowtie}$ email: zarebkohana@tbzmed.ac.ir; banif@tbzmed.ac.ir
} 
co-workers noted the initiation of necrotic and apoptotic changes in tumor cells is closely associated with temperature variation during $\mathrm{PTT}^{3}$. In an address to this issue, researchers have shown that PTT can induce autophagy in several studies ${ }^{22,23}$. They have also found that the role of autophagy in PTT is protective, so they suggested that autophagy inhibitors (HCQ, 3-MA) can increase PTT efficiency as an auxiliary treatment for PTT ${ }^{24,25}$. But the main questions here are whether the level of autophagy can lead to dormancy or increase the tumorigenesis ability of cells or not? Will the use of autophagy inhibitors at any level of autophagy induction increase the effectiveness of PTT? So, the PTT's major challenge is somehow controlling the exact parameters of PTT like the temperature inside the cancer cells or the tumor mass, near-infrared (NIR) irradiation time, and power of the laser for dictating the cancer cells to clean death.

According to the started clinical trials in human prostate cancer-bearing patients ${ }^{26}$, and considering the risks mentioned above and the lack of sufficient information, it seems that the unraveling of cancer cells' fate in response to different PTT regimes is indisputable. In the current experiment, we investigated the modulation of autophagy response and its final effects on tumorigenesis ability in human neuroblastoma cell line SH-SY5Y after exposure to lower and higher temperatures (in the range of mild hyperthermia) produced by albumincoated gold nanorods (AuNRs)-mediated PTT. The results of this study could help us develop efficient modalities in favor of cancer inhibition via PTT. For better understanding of our hypothesis, we prepared an illustration which is referred as Fig. 1.

\section{Results}

Synthesis, modification, and cellular uptake efficiencies of BSA-GNRs. In this study, AuNRs were developed by a seedless growth technique that produced CTAB capped nanorods (CTAB-AuNRs) ${ }^{26}$. TEM imaging showed monodispersed rod-shaped AuNRs with an average of $26.4 \mathrm{~nm}$ in length and $7 \mathrm{~nm}$ in width (Fig. 2A). Additionally, UV-Vis absorption spectra of AuNRs exhibited peak SPR frequency at $\sim 511 \mathrm{~nm}$, and we tuned the longitudinal peak SPR frequency to a sharp peak of $\sim 839 \mathrm{~nm}$, by modifying the aspect ratio to 3.77 (Fig. 2B).

DLS was employed to measure AuNRs size, zeta potential, and stability in aqueous solutions. Results showed that the CTAB-AuNRs had an average surface charge of $+22 \mathrm{mV}$ with an average hydrodynamic diameter of $32.1 \pm 1.3 \mathrm{~nm}$ (Fig. 2C). Functionalization (conjugation) of the AuNRs was performed through the exchange of CTAB by BSA to generate the BSA-AuNR complex. According to our data, BSA molecules were efficiently attached to the surface of AuNRs, which was indicated by the redshift of the plasmon peak of AuNRs in the UV-Vis spectrum (Fig. 2B), and the change of surface charge (zeta potential) analyzed by DLS (Fig. 2D). The UV-Vis spectra showed a peak at maximum absorbance around $854 \mathrm{~nm}$ for BSA-AuNRs. After BSA conjugation, the hydrodynamic size of BSA-AuNRs was slightly larger than that of CTAB-AuNRs, and BSA-AuNRs surface charge reached $-9.22 \mathrm{mV}$ (Fig. 2D). According to these data, the BSA-AuNR complex could be well stored in PBS solution and resuspended in a culture medium without aggregation for days. The above data suggested that BSA-AuNRs were suitable candidates for biological applications.

To test the cellular uptake of the BSA-AuNRs, we exposed the human neuroblastoma cell line, SH-SY5Y cells, to the BSA-AuNR complex for $4 \mathrm{~h}$. Based on our results, the efficiency of cellular uptake of BSA-AuNR nanoparticles was $15 \%$.

The photothermal conversion efficiency of BSA-AuNRs. To test whether BSA-AuNRs can introduce efficient photothermal effects, the temperature of BSA-AuNRs aqueous solution was recorded upon NIR irradiation using a digital thermometer while PBS-free nanoparticles were used as a control group (Fig. 3A). Upon excitation by incident radiation of appropriate wavelength, BSA-AuNRs generated sharp local heating by the photothermal conversion of the absorbed light energy, rendering these particular particles as extremely efficient "nano-heaters". Irradiating 4.5 ppm (uptaken nanoparticles) aqueous solution of BSA-AuNRs with a continuous wave laser $(808 \mathrm{~nm})$ for $8 \mathrm{~min}$ with $1.4 \mathrm{~W} / \mathrm{cm}^{2}$ power of laser resulted in a rise in temperature from 27 to $50^{\circ} \mathrm{C}\left(\Delta \mathrm{T}=23^{\circ} \mathrm{C}\right)$; however, when same solutions were irradiated with power densities $2 \mathrm{~W} / \mathrm{cm}^{2}$, the temperature of the solution increased from 27 to $80^{\circ} \mathrm{C}\left(\Delta \mathrm{T}=53^{\circ} \mathrm{C}\right)$ (Fig. 3A). Monitoring temperature change $(\Delta \mathrm{T})$ exhibited a rapid rise $\left(\Delta \mathrm{T}>7^{\circ} \mathrm{C}\right)$ within the first minute of irradiation, followed by a saturation trend $\left(\Delta \mathrm{T}<1^{\circ} \mathrm{C}\right)$ after $4 \mathrm{~min}$.

BSA-AuNRs plus PTT decreased viability of human SH-SY5Y cells. The safety and biocompatibility of BSA-AuNRs were investigated on SH-SY5Y cells using MTT assay and resulted compared to the CTABAuNRs. Figure 3 showed cell viabilities of SH-SY5Y treated with different concentrations of AuNRs (5, 10, 15, 20, 25, and $30 \mathrm{ppm}$ ) decorated with CTAB and BSA after $24 \mathrm{~h}$. The precise concentration of AuNRs in the CTAB-AuNRs and BSA-AuNRs complexes was calculated by AAS. The incubation of cells with CTAB-AuNRs promoted significant cytotoxicity at all concentrations $(5-30 \mathrm{ppm})$ (Fig. 3B). At the same time, the replacement of CTAB with BSA increased the survival rate and closed to the near-to-control levels. Of note, the SH-SY5Y cell viability increased from 8 in the CTAB-AuNR-treated group (20 ppm) to $95.33 \%$ in the BSA-AuNRs (20 ppm) group $(\mathrm{P}<0.0001)$. MTT assay showed that $90 \%$ of cells were viable even at the highest concentration of BSAAuNRs (30 ppm) after $24 \mathrm{~h}$ (Fig. 3B, P < 0.0001).

Next, the viability of SH-SY5Y cells was investigated after treatment with BSA-AuNRs and PTT. To this end, cells were treated with $30 \mathrm{ppm}$ BSA-AuNRs and irradiated with an 808-nm NIR laser, after $4 \mathrm{~h}$ incubation and 3 times washing with cold PBS. We noted that the temperature of groups increased up to 43 and $48{ }^{\circ} \mathrm{C}$ eight minutes after exposure to laser intensities 0.3 and $0.9 \mathrm{~W}$, respectively. Interestingly, data revealed the reduction of survival rate 85.6 to $24.6 \%$ compared to the control group as the temperature of the sample increased from 

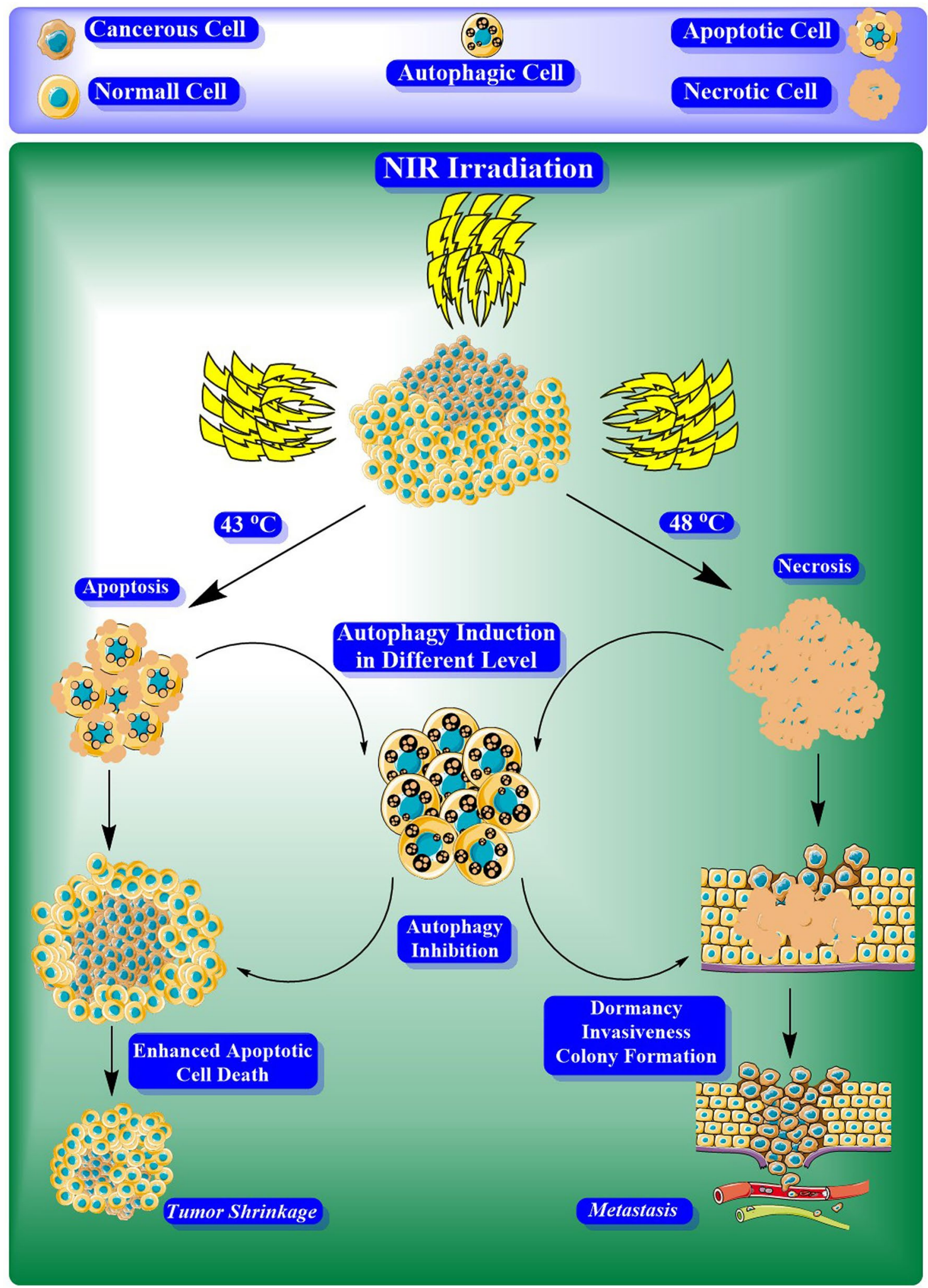

Figure 1. The concept of this study. May photothermal therapy invoke the tumorigenesis of cancer cells unwantedly by activating the autophagy pathway? 


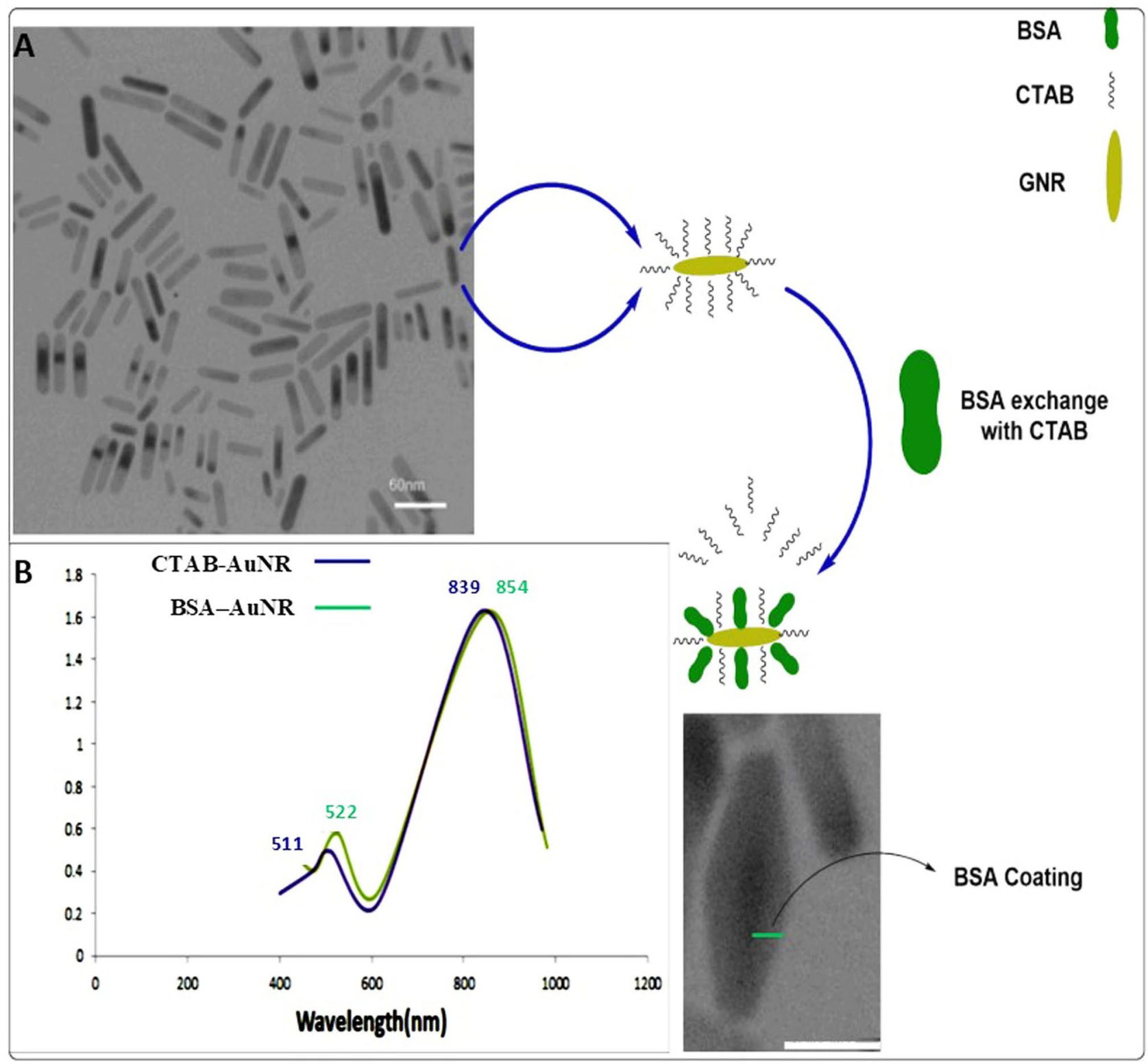

C

Zeta Potertsa Davreuson

D

Zeta Potential Distrbution
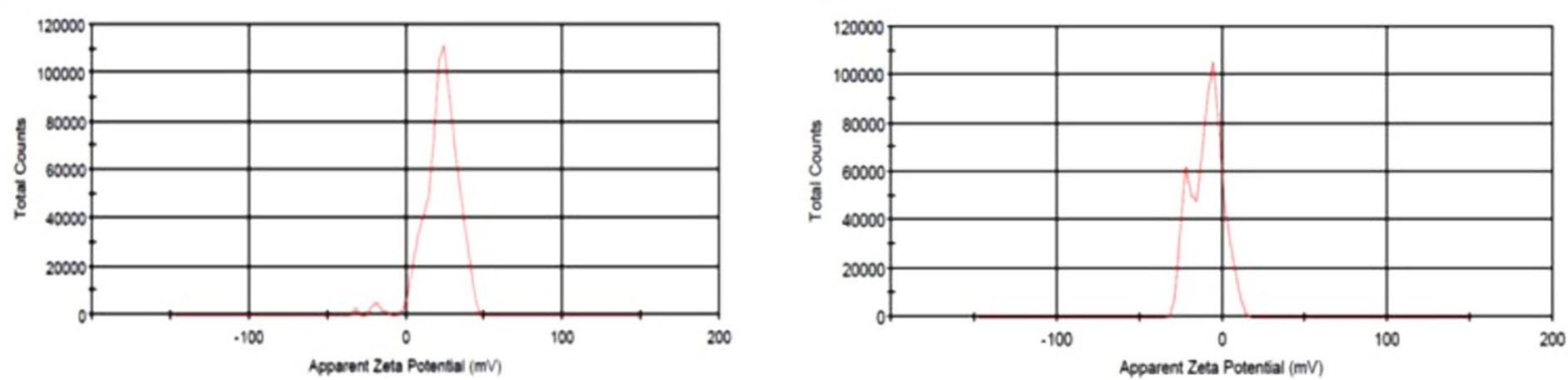

Figure 2. Characterization and performance monitoring of synthesized AuNRs. (A) Structural illustration and TEM image of AuNRs and BSA-AuNRs. (B) UV-Vis absorption spectra of CTAB-AuNRs and BSA-AuNRs. (C) Zeta potential of CTAB-AuNRs and (D) BSA-AuNRs were measured using DLS. 


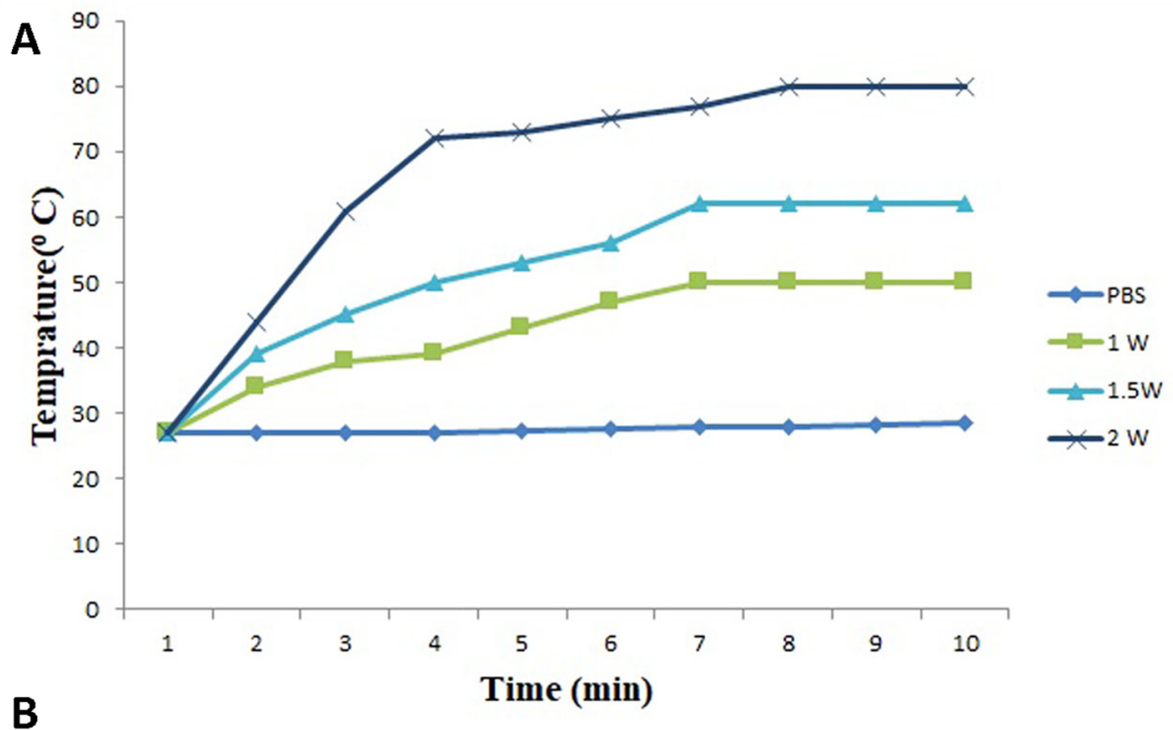

B

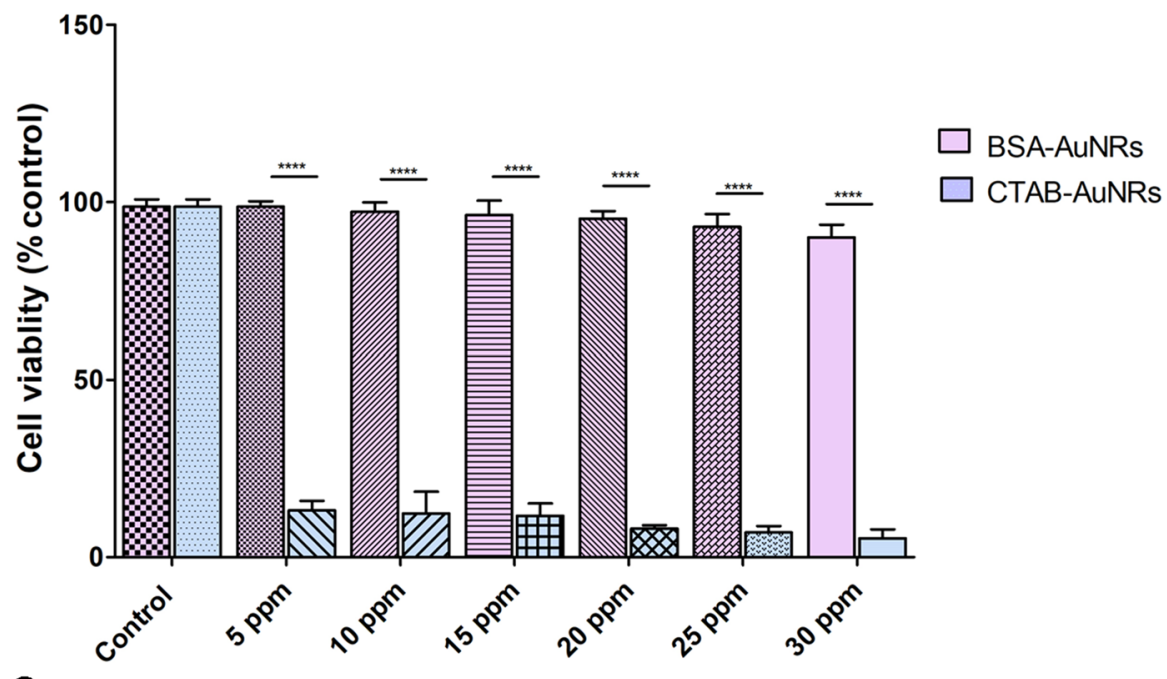

C

Concentration

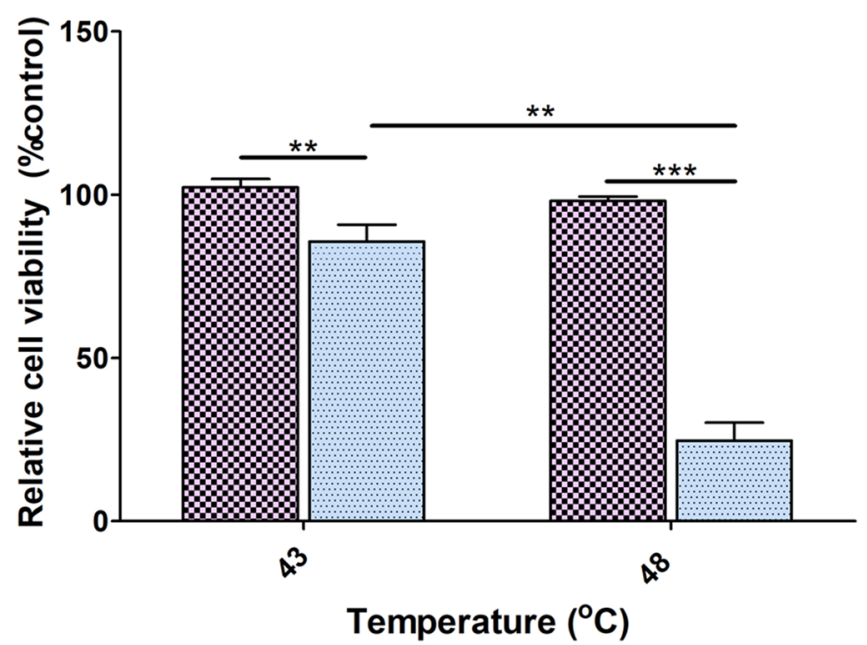

图 Laser

Laser+NP

Figure 3. Modeling of temperature elevation by PTT and MTT assay of nanoparticles. (A) The photothermal profiles of pure water and aqueous dispersions of BSA-AuNRs with $30 \mathrm{ppm}$ of BSA-AuNRs examined using 808-nm laser irradiation with a different power density of 1.4 and $2 \mathrm{~W} / \mathrm{cm}^{2}$. (B) Cell viability of CTAB-AuNRs and BSA-AuNRs at different concentrations (5-30 ppm). (C) Relative cell viability in response to 808 -nm laser irradiation with a power density of $2 \mathrm{~W} / \mathrm{cm}^{2}$ after incubation with or without $30 \mathrm{ppm}$ of BSA-AuNRs cell culture media. One-Way ANOVA and Tukey post hoc analysis. $(\mathrm{n}=3)$ ${ }^{* *} \mathrm{P}<0.01 ;{ }^{* * *} \mathrm{P}<0.001 ;{ }^{* * *} \mathrm{P}<0.0001$. 
A

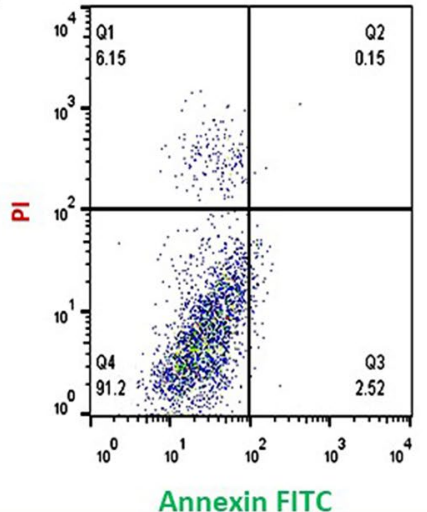

Control

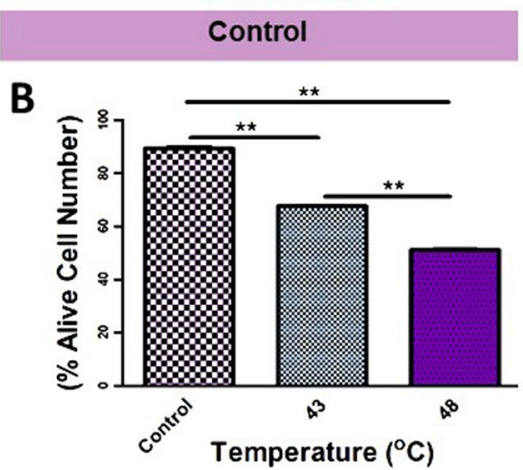

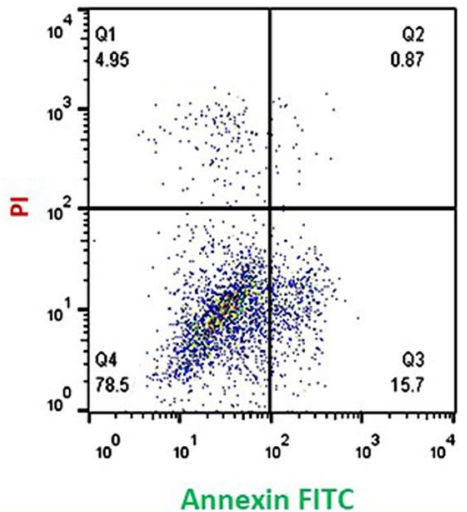

Temp 43

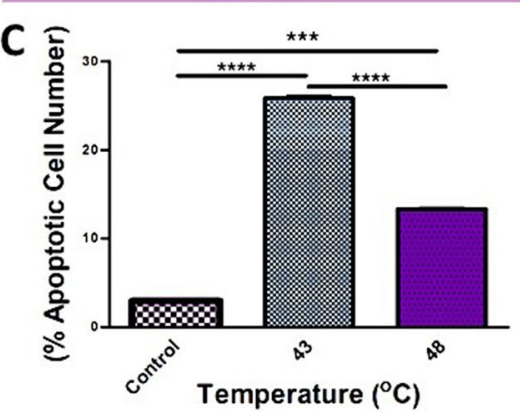

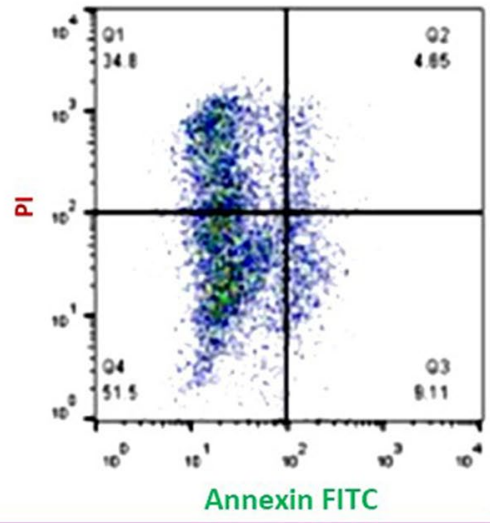

Annexin FITC

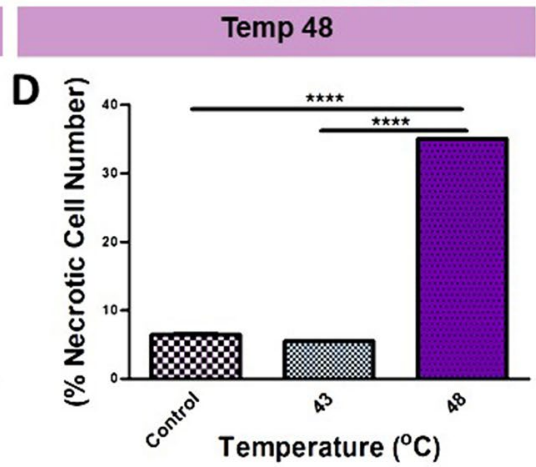

Figure 4. FITC-labeled annexin V/PI apoptosis assay. (A) Flow cytometry evaluation of apoptosis in different groups; Control, 43 , and $48^{\circ} \mathrm{C}$ (from left to right). (B) The number of alive cells after PTT induction between the mentioned groups $(\mathrm{P}<0.01)$. (C) The number of apoptotic cells after PTT induction between the abovementioned groups $(\mathrm{P}<0.0001)$. (D) The number of necrotic cells after PTT induction in the treated groups $(\mathrm{P}<0.0001)$. One-Way ANOVA and Tukey post hoc analysis $(\mathrm{n}=3) .{ }^{* *} \mathrm{P}<0.01 ;{ }^{* *} \mathrm{P}<0.001 ;{ }^{* * *} \mathrm{P}<0.0001$.

43 to $48^{\circ} \mathrm{C}$ (Fig. 3C, $\mathrm{P}<0.01$ ). These results suggested BSA-AuNRs have superior PTT efficacy and excellent biocompatibility in vitro.

Treatment of SH-SY5Y cells with BAS-AuNRs plus PTT induced apoptotic and necrotic cell death. To further evaluate the cell death mechanism, cells with different treatments were stained with Annexin V/FITC and PI and then processed by flow cytometry. As shown in Fig. 4A, neither early apoptosis nor late apoptosis was detected in the control and BSA-AuNRs (data not shown) groups. Treatment of cells with the combination of BSA-AuNRs and PTT induced apoptotic changes (early apoptotic cells: 20.1\%; late apoptotic cells: $5.43 \%)$ necrotic cell death $(18.2 \%)$ at $43{ }^{\circ} \mathrm{C}$ (Fig. 4C,D). According to our data, we showed a significant increase in the number of necrotic cells at higher temperatures $\left(48^{\circ} \mathrm{C}\right)$ compared to groups $43^{\circ} \mathrm{C}$ (Fig. $4 \mathrm{D}$, $\mathrm{P}<0.0001)$. These results revealed that the increase of intracellular temperature under PTT could change the cell death type. It seems that higher temperatures induced rapid necrotic cell death rather than slow cell death apoptosis. Taken together, PTT effectively exerts tumoricidal effects on human SHSY-5Y cells, and the type of cytotoxicity is closely associated with ambient temperature (Fig. 4B-D).

Assessment of autophagic response by flow cytometry assay. The autophagic response was also monitored using flow cytometry analysis. Data showed that the percent of apoptotic cells was not statistically significant in cells treated with BSA-AuNRs compared to the non-treated group (Fig. 4B). By increasing the temperature from 43 to $48^{\circ} \mathrm{C}$ (Fig. 5A), the number of apoptotic cells expressing LC3 was also increased. Despite an increase in the number of LC3-positive cells in groups exposed to the combination of BSA-AuNRs and PTT, these changes were not significant. Also, our findings show that in addition to the increase of autophagic cell percentage, the amounts of LC3 increase in response to the temperature elevation (Fig. 5B,C). Besides, we confirmed these findings qualitatively (Fig. 5D). These data showed that the treatment of human cancer cells with BSA-AuNRs plus PTT could alter the number of cells entering apoptosis.

Exposure of AuNRs to PTT changed the expression of autophagy machinery effectors in a temperature-dependent manner. To evaluate the effect of temperature on certain autophagy responses in human $\mathrm{SH}-\mathrm{SY} 5 \mathrm{Y}$ cells, the expressions of autophagy-related genes were monitored in two temperatures $\left(43^{\circ} \mathrm{C}\right.$ and $\left.48^{\circ} \mathrm{C}\right)$ after treatment with the combination of AuNRs and PTT by RT ${ }^{2}$ Profiler PCR Arrays-Human Autophagy ${ }^{27}$. Our findings showed that in a lower and higher level of mild temperature hyperthermia $\left(43^{\circ} \mathrm{C}\right.$ 


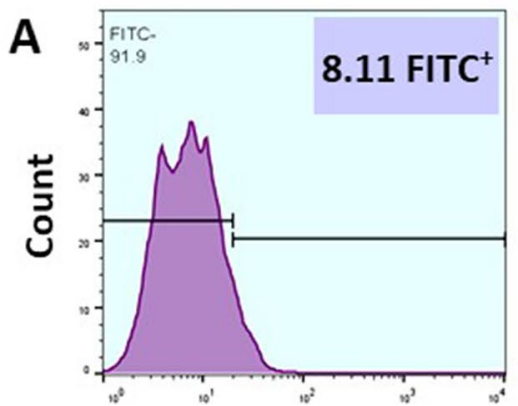

FLH1: FITC

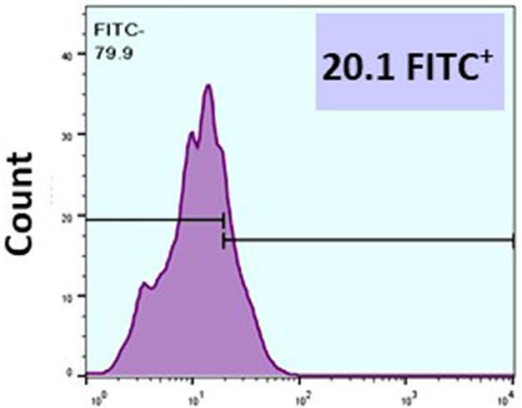

FLH1: FITC

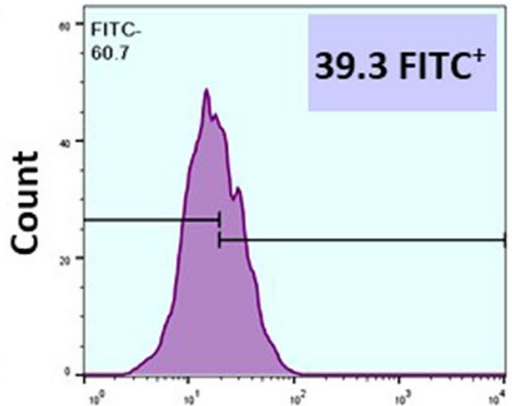

FLH1: FITC
B

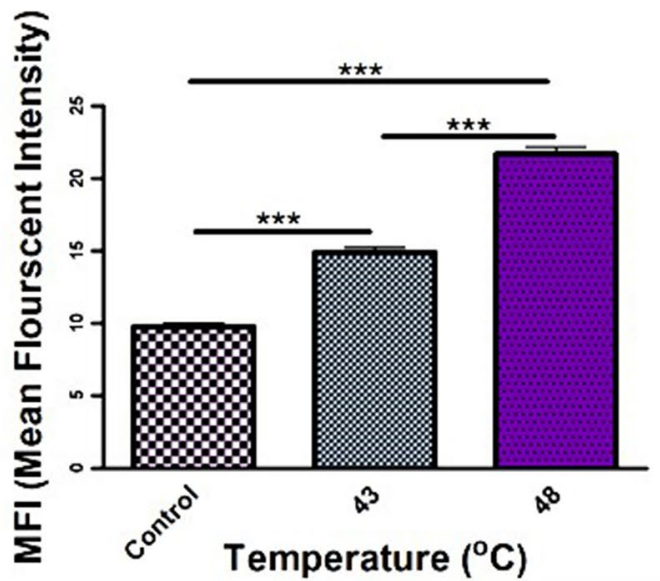

Temp 43
Temp 48

\section{Control}

C

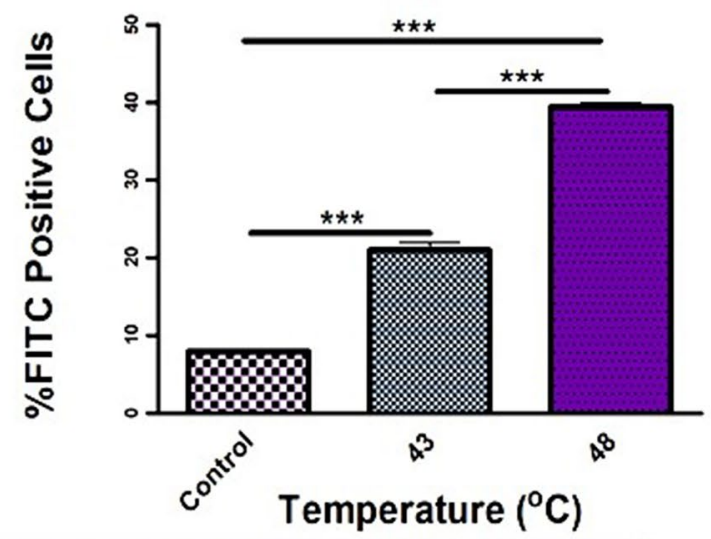

D
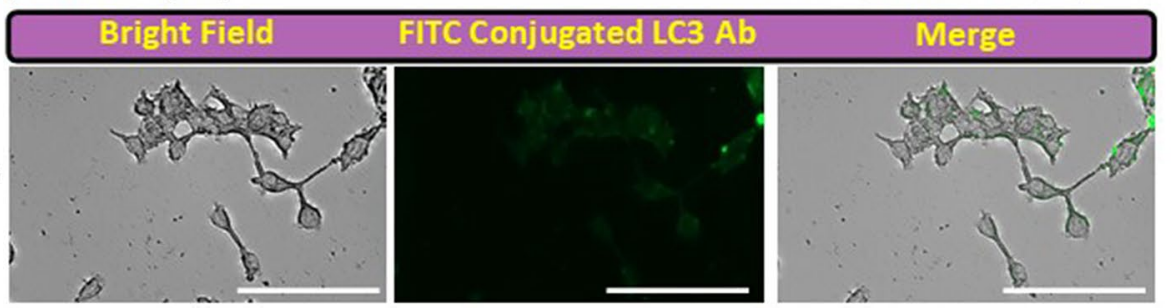

$43^{\circ} \mathrm{C}$ Treated Cells
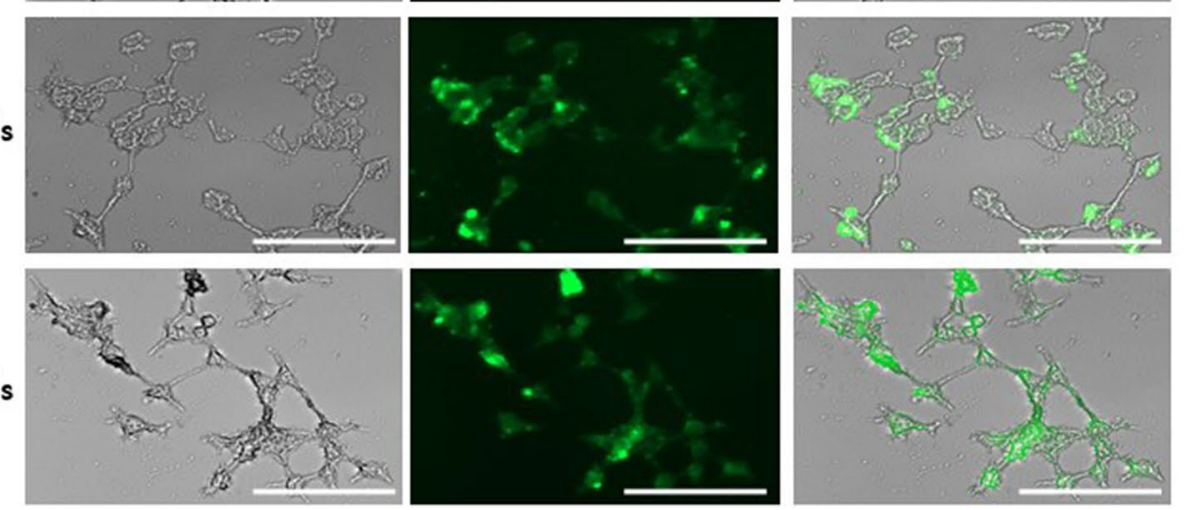

Figure 5. Quantitative and qualitative evaluation of autophagy induction. (A,C) Flow cytometry histogram of treated cells in different groups. As were showed in this section, the percentage of positive FITC-conjugated LC3 antibody cells increased from left to right by increasing the induced temperature $(\mathrm{P}<0.001)$. (B) The mean fluorescent intensity of treated groups. Our results showed that in addition to the number of FITC-labeled LC3 antibody-positive cells, the intensity of signals significantly increases by temperature elevation $(\mathrm{P}<0.001)$. (D) Qualitatively evaluation of autophagy by fluorescent microscopy. It was showed that the autophagy levels in the cells increase by induction of PTT. One-Way ANOVA and Tukey post hoc analysis $(\mathrm{n}=3){ }^{* * *} \mathrm{P}<0.001$. 

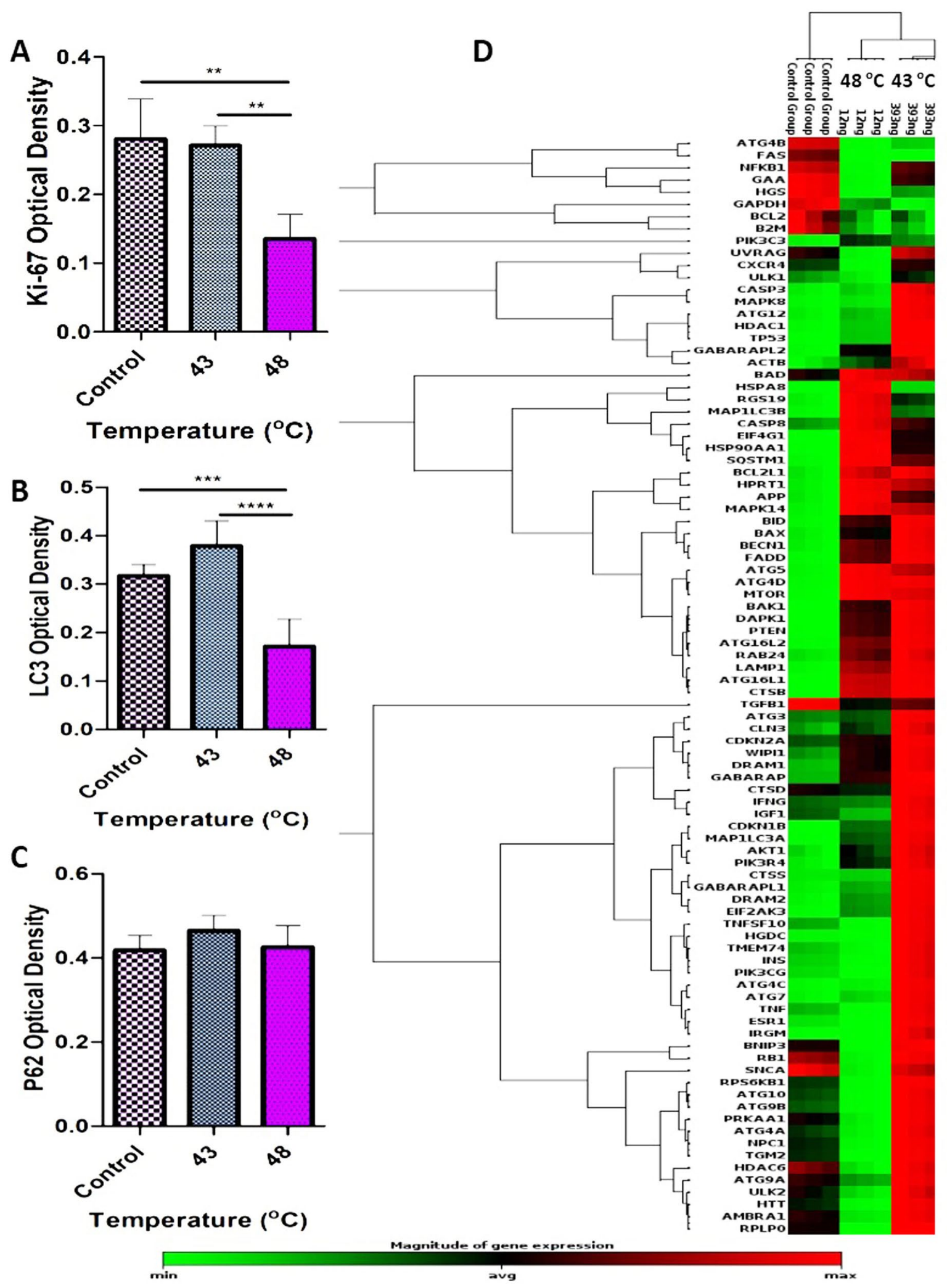

Temperature $\left({ }^{\circ} \mathrm{C}\right)$

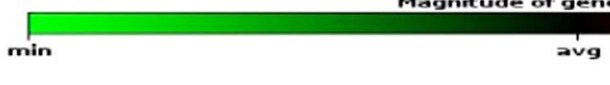

Figure 6. Protein level of Ki-67, P62, and LC3 measured by ELISA and PCR array of 86 genes involved in autophagy machinery. (A) Ki-67 protein level (as a proliferation indicator), significantly decreased followed by 43 and $48^{\circ} \mathrm{C}$, which shows the reverse effect of temperature elevation on the cell's proliferation ability $(\mathrm{P}<0.01)$. (B) LC3 protein level (as autophagy indicator) showed different behavior of cells in response to temperature elevation $(\mathrm{P}<0.0001)$. (C) Interestingly, our results showed that the $\mathrm{P} 62$ protein level does not change significantly in response to temperature increase. (D) Phylogenic tree of 86 genes related to autophagy. Our results showed that 54 genes from those changed in response to the PTT. One-Way ANOVA and Tukey post hoc analysis $(\mathrm{n}=3)$. ${ }^{* \star} \mathrm{P}<0.01 ;{ }^{* *} \mathrm{P}<0.001 ;{ }^{* * *} \mathrm{P}<0.0001$. 
and $48{ }^{\circ} \mathrm{C}$ ) significantly increased the expressions of several autophagy-related indicators in the SH-SY5Y cell line compared to the control group (Fig. 6D). The results of the transcriptomic analysis showed a significant change in the expression of effectors playing a critical role in different components of autophagy machinery like chaperone-mediated autophagy (CMA) and macroautophagy (Fig. 6D, Supp. Data).

Macroautophagy machinery components. The autophagy regulating machinery is composed of different genes that control three distinctive processes, including macroautophagy, microautophagy, and $\mathrm{CMA}^{28}$. Through the invagination of the lysosomal membrane, microautophagy controls the internalization of cytosolic recycled proteins and organelles ${ }^{29,30}$. Of 86 genes associated with autophagy, the expression of 54 genes was changed in response to temperature fluctuation induced by PTT protocol (Fig. 6D, Supp. Data). According to our data, the expression of most genes was up-regulated at $43{ }^{\circ} \mathrm{C}$ and $48^{\circ} \mathrm{C}$. It seems that the intensity of these changes was different between 43 and $48^{\circ} \mathrm{C}$ groups (Fig. 5D). The association of these effectors with other signaling pathways seems to dictate specific cell behavior.

Vacuole formation, induction, and nucleation. Vacuole formation, vacuole targeting, ubiquitination, and autophagosome-lysosome linkage are the most important components of macroautophagy ${ }^{31-33}$. The autophagyrelated genes (ATG) have an indisputable role in controlling the autophagosome formation and macroautophagy processes $^{34}$. As shown in Fig. 6, the expression profile of some genes [Becn1 (BECN), Ulk1 (the Unc-51 like kinase 1 (C. elegans)], RGS1, GABARAP, Atg9a, Atg4a, and ATG12 involved in the vacuole formation were not significantly changed in groups $43{ }^{\circ} \mathrm{C}$ and $48^{\circ} \mathrm{C}$ in comparison with the control group (Supp. Data). On the contrary, the up-regulation of ATG16L1 (1364.50-fold vs. 1164.10-fold), ATG4d (6.43-fold vs. 6.52-fold), ATG5 (2.63-fold vs. 2.94-fold), GABARAPL2 (3.22-fold vs. 2.12-fold), MAP1LC3A (LC3-I: 12.25-fold vs. 5.05-fold), MAP1LC3B (LC3-II: 2.05 -fold vs. 4.58 -fold) was indicated at $43{ }^{\circ} \mathrm{C}$ and $48{ }^{\circ} \mathrm{C}$, respectively. We found that the expression of two genes is different in human cancer cells exposed to different temperatures. Contrary to the results of group $43^{\circ} \mathrm{C}$, both genes AMBRA1 (-2.05-fold) and ATG9B (-4.07-fold) were down-regulated at $48^{\circ} \mathrm{C}$. The exposure of human SH-SY5Y cells up-regulated ATG9B (2.44-fold) and IRGM (46.37-fold) at $43^{\circ} \mathrm{C}$. We found down-regulation of ATG4B in both $43{ }^{\circ} \mathrm{C}(-3.28$-fold $)$ and $48{ }^{\circ} \mathrm{C}(-5.08$-fold) groups compared to the non-treated control (Fig. 6D, Supp. Data).

Ubiquitination and phagophore expansion. Two ubiquitin-like systems, including LC3 conjugation and Atg12Atg5-Atg16L, are crucial partners for the elongation of the pre-autophagosomal structure (PAS) system ${ }^{35}$. Data showed that except Atg12, Atg5 and Atg16L were up-regulated in the neuroblastoma cell line during exposure to $43{ }^{\circ} \mathrm{C}$ (Atg5: 2.63-fold and Atg16: 2.94) and $48{ }^{\circ} \mathrm{C}$ (Atg5: 1346.50-fold and Atg16: 1164.10-fold) (Fig. 6D, Supp. Data). These two systems work in two different manners. By an enzymatic function of Atg7 and Atg10, the protein Atg12 is attached to the Atg5 factor. After that, the Atg12-Atg 5 complex binds non-covalently to the Atg16L protein, and this complex serves as an e3-like ubiquitin ligase for autophagosomal membrane formation and development ${ }^{34}$.

Secondly, Atg7 and Atg3 cooperatively connect another ubiquitin-like protein (LC3) with phosphatidylethanolamine (PE) to increase the intracellular concentration of LC3II. LC3-II is touted as a final mediator which participates in the elongation phase of the autophagosome ${ }^{36}$. In the SH-SY5Y cells treated with mild hyperthermia, the expression level of LC3-I and MAP1LC3B was up-regulated at $43^{\circ} \mathrm{C}$ and $48^{\circ} \mathrm{C}$. However, the intensity of expression varied in both groups. This different but aligned pattern in the expression of LC 3 confirmed the fact that autophagy could be stimulated at different temperatures with a certain activity. These features lead to different consequences and behavior in cancer cells ${ }^{37}$. Another important gene that belongs to autophagy machinery, HDAC6 (Histone deacetylase 6), is crucial for ubiquitin-based control of autophagy and facilitating the lysosome-autophagosome attachment ${ }^{38}$. The combination of AuNRs and PTT did not alter the expression of HDAC6 at $43^{\circ} \mathrm{C}$ and $48^{\circ} \mathrm{C}$ groups compared to the control (Fig. 6D, Supp. Data).

Vacuole targeting and autophagosome-lysosome linkage. The next step after autophagosome formation is tethering and merging the autophagosome with lysosomal vacuole and, subsequently, the release of autophagic vesicle contents into the lysosomal inner space ${ }^{39}$. In the following steps, the contents are degraded by lipases and hydrolases in the lysosomes. Finally, the products of degradation processes are released into the cytosol by efflux transporters ${ }^{40}$. The transcriptome profile of some associated proteins involved in the fusion process has been evaluated in this study. Lamp1, the Lysosomal-associated membrane protein 1 gene, was significantly up-regulated at $43{ }^{\circ} \mathrm{C}$ (3.64-fold) and $48^{\circ} \mathrm{C}$ (3.08-fold), respectively. In contrast, Atg $4 \mathrm{~b}$ was significantly downregulated $43{ }^{\circ} \mathrm{C}(-3.28$-fold $)$ and $48{ }^{\circ} \mathrm{C}(-5.08$-fold $)$. Atg4c, another autophagosome-lysosome linkage-related gene, was up-regulated ( 3.31 -fold) at $43{ }^{\circ} \mathrm{C}$, while the treatment of cells at $48^{\circ} \mathrm{C}$ did not alter transcription level compared to the control (Fig. 6D, Supp. Data). The expression of GABARAP, the Gamma-aminobutyric acid (GABA) A receptor-associated protein-like, was not changed at both temperatures. Concerning these findings, it seems that the autophagosome-lysosome linkage step of autophagy was stimulated more effectively at $43^{\circ} \mathrm{C}$ rather than $48^{\circ} \mathrm{C}$.

Chaperone-mediated autophagy. CMA is a specific pathway that cells used directly for lysosomal degradation of assembled proteins without any lysosomal membrane changing following intra/extracellular stresses ${ }^{35}$. CMA signaling can be controlled by some of the heat shock proteins like $71 \mathrm{kDa}$ protein (Hsc70), also known as HSPA8, an important member of the heat shock protein 70 family (Hsp70). HSPA8, in combination with HSP90AA1 (cytosolic class A member 1 co-chaperones) forms chaperone/substrate complex. This complex uses a pentapeptide motif (KFFRQ) targeted misfolded cytosolic proteins ${ }^{41}$. In our study, the expression profile of 

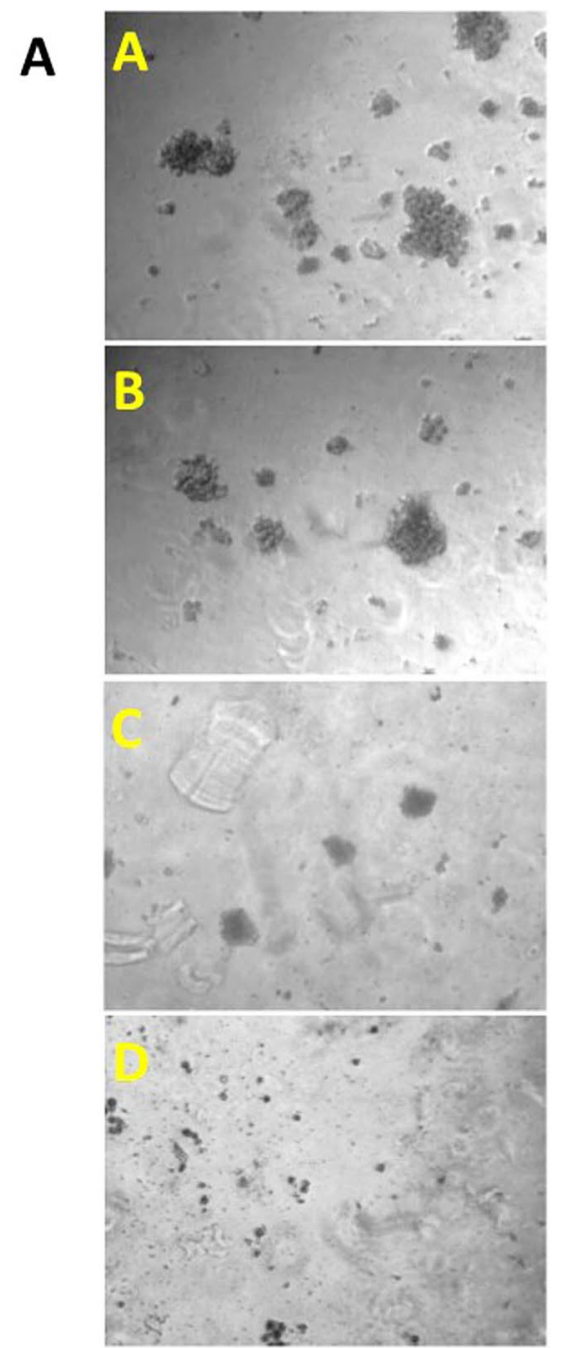

B
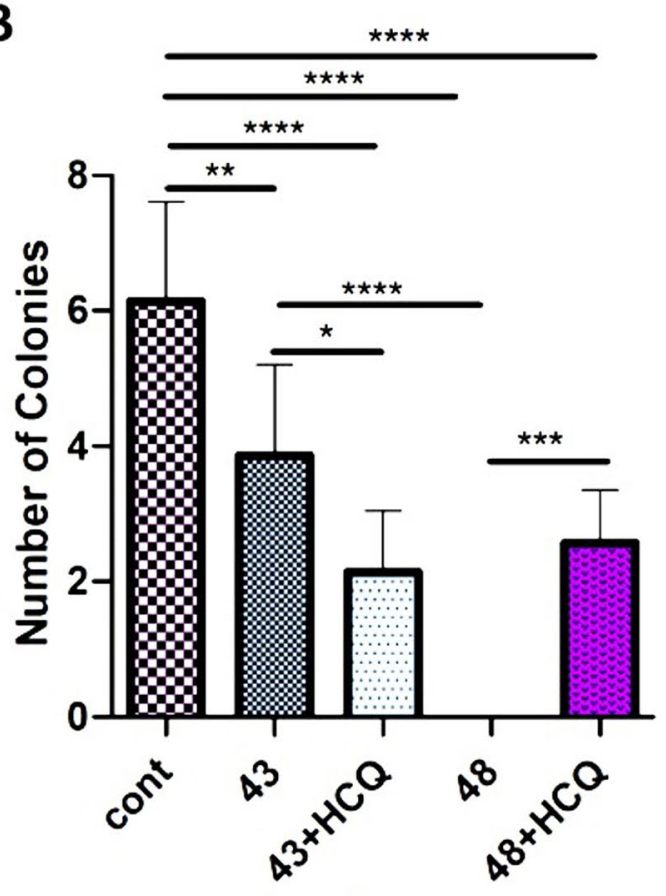

Treatments

Figure 7. Tumor formation assay. (A) A-E images show the colony formation ability in response to two different PTT regimens, in the presence and absence of HCQ, qualitatively. (B) Statistical analysis of colony formation assay shows that human neuroblastoma cell line behavior completely different in response to 43 and $48{ }^{\circ} \mathrm{C}$. In the former, autophagy has a protective role in cancer cells fate $(\mathrm{P}<0.05)$, while in the latter, autophagy exerts a cytotoxic effect on cancer cells $(\mathrm{P}<0.001)$. One-Way ANOVA and Tukey post hoc analysis. $(\mathrm{n}=3)$. ${ }^{\star} \mathrm{P}<0.05 ;{ }^{\star \star} \mathrm{P}<0.01 ;{ }^{\star * \star} \mathrm{P}<0.001 ;{ }^{* * \star} \mathrm{P}<0.0001$.

HSP90AAlgene was not significantly changed in response at $43{ }^{\circ} \mathrm{C}$ compared to $48{ }^{\circ} \mathrm{C}$. This finding shows that PTT parameters used in this study cannot properly alter the expression of HSP90AA1. Interestingly, the expression of HSPA8 is up-regulated only at $48^{\circ} \mathrm{C}(5.45$-fold $)$. These results show that CMA is activated at $48^{\circ} \mathrm{C}$ (Fig. 6D, Supp. Data).

The activation of autophagy by PTT alters the colorogenic capacity of human SH-SY5Y cells. In this study, we used the colony formation assay to investigate the PTT's effect at two different temperatures, $43{ }^{\circ} \mathrm{C}$, and $48{ }^{\circ} \mathrm{C}$, on human SH-SY5Y cells. Our results showed that incubation of cells at $43{ }^{\circ} \mathrm{C}$ had protective effects on the cancer cells, while the promotion of autophagy at $48{ }^{\circ} \mathrm{C}$ led to cytotoxicity in SH-SY5Y cells (Fig. 7A). To show the protective effect of autophagy in SH-SY5Y cells after being exposed to 
PTT, we used an autophagy inhibitor, $10 \mu \mathrm{M}$ HCQ. We noted that the incubation of cells with HCQ sensitized them to the detrimental effect of PTT, which was blunted by the activation of autophagy. Data confirmed that the number of colonies was significantly decreased in the presence of HCQ after being exposed to $43^{\circ} \mathrm{C}$. This finding suggests that autophagy stimulation by PTT at $43{ }^{\circ} \mathrm{C}$ leads to increased SH-SY5Y cell survival, indicating the protective effect of autophagy in cancer cells exposed to mild hyperthermia. The inhibition of the final phase of autophagy by HCQ contributes to the accumulation of toxic metabolites and unfolded/misfolded proteins, inducing apoptosis ${ }^{42}$. In contrast, the exposure of cancer cells to higher temperatures, such as $48^{\circ} \mathrm{C}$ destroyed many cells quickly and inhibit colorogenic capacity (Fig. 7B). These findings are consistent with the results obtained from the study of genes involved in autophagy. The changes in the expression profile of genes in response to environmental stresses confirmed, and its possible role in the alteration of cancer cell properties have been established in the last decade ${ }^{43}$.

The induction of autophagy can result in three types of consequences, including dormancy, invasiveness, and death ${ }^{44,45}$. Along with this statement, we measured the expression level of Ki-67 protein as a marker of cell division using ELISA (Fig. 6A). Based on our data, Ki-67 was not changed in cells exposed to $43^{\circ} \mathrm{C}$ compared to the control. In contrast, applying $48^{\circ} \mathrm{C}$ inhibited significantly the synthesis of Ki-67 and LC3 compared to non-treated control cells and $43^{\circ} \mathrm{C}$ group (Fig. 6A,B). Our results showed the up-regulation of important genes involved in dormancy, including CTSB, P53, IFN-B, IFN-Y, CDKN1B (P27), CDKN1A (P21), and PTEN at $43{ }^{\circ} \mathrm{C}$ group compared to the $48{ }^{\circ} \mathrm{C}$ group (Supp. Data, Fig. 6C,D). Considering the potency of $43{ }^{\circ} \mathrm{C}$ to induce the synthesis of nuclear factor Ki-67 and stimulate colorogenic capacity and autophagic response in the $\mathrm{SH}$ SY5Y cells (Fig. 6A), we could hypothesize that the incubation of cancer cells in mild temperatures could inhibit active dynamic growth but simultaneously promote autophagic response which is a compensatory response to resist again insulting stimuli. The activation of certain genes in autophagy signaling could trigger other resistance mechanisms such as dormancy in the host cells (Supp. Data). In support of this notion, the blockade of autophagic response could decrease the cancer cells' survival rate compared to control matched groups. However, it should not be forgotten that the stimulation of autophagic responses to a certain extent can be protective. The over-stimulation of autophagy effectors could alter the expression and activity of other parallel signaling pathways, such as apoptosis, as seen in the groups exposed to $48^{\circ} \mathrm{C}$. Data from the flow-cytometry analysis further supported these features (Fig. 5).

Interestingly, the expression of autophagy machinery genes related to the invasion was increased at $48^{\circ} \mathrm{C}$. Despite the loss of a large number of cells at $48^{\circ} \mathrm{C}$, cells can form colonies in the presence of HCQ (Fig. 7B). It seems that the distinct effect of temperature on the modulation of autophagy-related genes could be responsible for certain cancer cells' behavior. Consistent with our data, it has been shown that the tumor formation process that arises from the Ras pathway activation requires high levels of autophagy for survival and cell proliferation ${ }^{42}$.

Concerning the induction of some effectors in autophagy signaling such as MAPK14, LAMP1, eIF4E, eIF4GI, ATG16L1, CDKN1A, CDKN1B, CTSB, and GABARAPL1 and their contribution to metastasis, we conclude that some genes have a regulatory role over other counterparts. For instance, EIF4E and eIF4G translation initiation factors are involved in tumorigenesis and patient survival (Tables 1,3). The important role of these factors in cell migration, amplification of EMT promoters, and metastasis has been demonstrated previously (Table 2). Like ARHI, some genes play a crucial role in controlling the outcome of autophagy ${ }^{13,46}$. It has been shown that the re-expression of ARHI can lead to autophagic cell death even in the presence of $\mathrm{HCQ}^{47}$.

\section{Discussion}

According to our findings, the induction of autophagy using AuNRs seems to be completely dependent on the generation of sudden intracellular temperature. The induction of autophagy at two temperatures $\left(43^{\circ} \mathrm{C}\right.$ and $48^{\circ} \mathrm{C}$ ) resulted in completely different consequences. Based on our findings, the BSA-AuNR complex with NIR to heat conversion efficiency and good biocompatibility to $30 \mathrm{ppm}$ could be pretty well candidates for photothermal therapy. Also, an increase of intracellular temperature up to $43^{\circ} \mathrm{C}$ caused clean cell death (apoptosis) compared to higher temperatures $\left(48^{\circ} \mathrm{C}\right)$ (necrotic). As we mentioned earlier, the type of cell death has a profound effect on the fate of other cells located in the tumor. Interestingly, LC3 expressing apoptotic cells enhanced by increasing the temperature from 43 to $48^{\circ} \mathrm{C}$ which shows autophagic cell death (Fig. 5D, 6B). These data showed that the treatment of human cancer cells with BSA-AuNRs plus PTT could alter the number of cells entering apoptosis. Based on our best knowledge this is the first report about temperature-dependent autophagic cell death by PTT.

For the detailed address of this behavior, we showed that of 86 genes associated with autophagy, the expression of 54 genes was changed in response to temperature variation. Up to now, it has been confirmed that changes in the expression profile of autophagy-related genes contributed to the fate of cancer cells like cell death type, metastasis ability, colony formation, invasiveness, and dormancy which are summarized in (Tables 1, 2, 3). Also, $\mathrm{Lu}$ et al. showed that the expression intensity or level of autophagy-related genes affects the cell fate ${ }^{1}$. Interestingly, our results illustrated that the intensity and pattern of these changes were different between 43 and $48^{\circ} \mathrm{C}$ (Tables 1 and 2, Supp. Data). In addition, the pattern of some expressed genes is in contrast to each other in two different temperatures like AMBRA1, ATG9B, LC3-I, MAP1LC3B, Atg5, Atg4c, and Atg16. As aforementioned, these findings added a notion that changes in the autophagy effectors contributing to autophagy levels which resulted in altering cell behavior and fate. Furthermore, we showed for the first time that the CMA pathway ${ }^{2}$, which is controlled by some of the heat shock proteins like HSPA8 is activated at $48{ }^{\circ} \mathrm{C}$.

All together molecular, transcriptional, and colony formation experiments in this work demonstrated that the low level of mild hyperthermia $\left(43^{\circ} \mathrm{C}\right)$ has protective effects on the cancer cells, while the higher level of mild hyperthermia $\left(48^{\circ} \mathrm{C}\right)$ led to cytotoxicity in SH-SY5Y cells. Therefore, despite the induction of more apoptosis, our findings suggest that autophagy stimulation by PTT at $43{ }^{\circ} \mathrm{C}$ leads to increased autophagic survival and 


\begin{tabular}{|c|c|c|c|c|c|c|}
\hline \multirow[b]{2}{*}{ Gene expression changes } & \multirow[b]{2}{*}{ Cellular outcome } & \multirow[b]{2}{*}{ Effect(s) } & \multirow[b]{2}{*}{ Consequences on tumor fate } & \multirow[b]{2}{*}{ References } & \multicolumn{2}{|c|}{ Our study findings } \\
\hline & & & & & $43^{\circ} \mathrm{C}$ & $48^{\circ} \mathrm{C}$ \\
\hline \multirow[b]{2}{*}{ Activation of GABARAPL1 } & Autophagy activation & \multirow[b]{2}{*}{ Increase ROS } & \multirow[b]{2}{*}{ Tumor suppression } & \multirow[b]{2}{*}{37,50} & \multirow[b]{2}{*}{2.04} & \multirow[b]{2}{*}{ NSC } \\
\hline & $\begin{array}{l}\text { Deletion of damaged Mito- } \\
\text { chondria }\end{array}$ & & & & & \\
\hline ATG5 & \multirow{2}{*}{ Autophagy inhibition } & Oxidative stress & \multirow{2}{*}{ Tumor suppression } & \multirow{2}{*}{51} & ATG5: $\mathbf{2 . 6 3}$ & ATG5: $\mathbf{2 . 9 4}$ \\
\hline ATG7 (deletion) & & Damaged Mitochondria & & & ATG7: $\mathbf{2 . 1 7}$ & ATG7: NSC \\
\hline \multirow{2}{*}{ Autophagy activation } & \multirow{2}{*}{ ATG4D over-expression } & $\begin{array}{l}\text { Intracellular LC3-B/P62 accu- } \\
\text { mulation }\end{array}$ & \multirow{2}{*}{ Tumor suppression } & \multirow{2}{*}{52} & \multirow{2}{*}{6.43} & \multirow{2}{*}{6.52} \\
\hline & & $\begin{array}{l}\text { Autophagosome formation } \\
\text { abortion }\end{array}$ & & & & \\
\hline \multirow{2}{*}{ Atg4B (over-expression) } & \multirow{2}{*}{ Autophagy inhibition } & LC3-PE degradation & \multirow{2}{*}{ Tumor suppressive } & \multirow{2}{*}{53} & $-3,28$ & 508 \\
\hline & & LC3 sequestration in the cytosol & & & -3.20 & 3.00 \\
\hline & Atg4a & & & & NSC & 1.37 \\
\hline DNA damage & Atg $4 \mathrm{c}$ & Autophagy activation & $\begin{array}{l}\text { Tumor suppression by } \\
\text { p53-mediated apoptosis }\end{array}$ & 54 & 3.31 & NSC \\
\hline & p53 (activation) & & & & 3.24 & NSC \\
\hline UVRAG up-regulation & Autophagy deficiency & - & Tumor suppression & 55 & NSC & 2.21 \\
\hline & & Decreased survival capacity to & Tumor suppression (Decrease & & 2.63 & 2.94 \\
\hline Autophagy deficiency & ATG5 and ATG12 deficiency & metabolic stress & $\begin{array}{l}\text { in colonization and survival } \\
\text { capability) }\end{array}$ & 56 & NSC & NSC \\
\hline Dormancy activation & P53 overexpression induced by & $\begin{array}{l}\text { Pentose phosphate pathway } \\
\text { destruction }\end{array}$ & Cell death & 57 & 3.24 & NSC \\
\hline & & Increased ROS & Dormancy induction by IFN-b & & & \\
\hline & & & Tumor suppression & & & \\
\hline ER stress & $\begin{array}{l}\text { K-RAS dependent Eif2ak3 } 3^{-/-} \\
\text {MEFs }\end{array}$ & $\begin{array}{l}\text { The decrease in VCIP and PDG- } \\
\text { FRB (angiogenic stabilizer) }\end{array}$ & ECM destruction & 58 & 5.88 & 2.20 \\
\hline & & & Vast hemorrhage & & & \\
\hline & & & The decrease in EMT promoter & & & \\
\hline Autophagy manipulation & eIF4E/eIF4GI knockdown & $\begin{array}{l}\text { The decrease in ERa, SMAD5, } \\
\text { NFkB, CyclinD1, c-MYC and }\end{array}$ & Increase in EMT inhibitors & 59 & 1049.1 & 1904.2 \\
\hline & & HIFla & $\begin{array}{l}\text { The decrease in migration } \\
\text { capability }\end{array}$ & & & \\
\hline $\begin{array}{l}\text { HSPA8(HSC70) complex } \\
\text { formation }\end{array}$ & $\begin{array}{l}\text { Chaperone mediated autophagy } \\
\text { (CMA) }\end{array}$ & Cargo delivery to the lysosome & Tumor protection by autophagy & 60 & NSC & 5.45 \\
\hline JFN- $\gamma /$ STATl activation & Downregulation of Cyclin E, A, & Downregulation of CDK4 and & Cell cycle arrest & 61 & 286 & NSC \\
\hline IFN- & $\mathrm{D} 1,2,3$ & CDK6 & Cancer cell dormancy & & 2.00 & NOC \\
\hline AMBRA1 & AMBRA1 role in the modulation & Intracellular switch between & Colony formation & 62 & NSC & 205 \\
\hline AMBRA1 & $\begin{array}{l}\text { of C-MYC phosphorylation and } \\
\text { stability }\end{array}$ & autophagy and apoptosis & Autophagic survival & 2 & NSC & 2.05 \\
\hline Inherent ATG5 or autophagy & $\begin{array}{l}\text { These mutations may contribute } \\
\text { to cancer development by }\end{array}$ & Intracellular inherent autophagy & $\begin{array}{l}\text { Recurrence, Chemotherapy } \\
\text { desensitization }\end{array}$ & 63,64 & 2.63 & 2.94 \\
\hline & $\begin{array}{l}\text { deregulating the autophagy } \\
\text { process }\end{array}$ & & Increase of dormancy frequency & & & \\
\hline & BID knockdown resulted in & & Dormancy hub gene, Survival & & & \\
\hline CTSB & $\begin{array}{l}\text { induced apoptosis and a shift of } \\
\text { cell death towards autophagy }\end{array}$ & $\begin{array}{l}\text { dormancy } \\
\text { dist or the nub genes for }\end{array}$ & Self-renewal & 65,66 & 10.97 & 9.68 \\
\hline & $\begin{array}{l}\text { Increase of Beclin } 1 \text { and MAP I } \\
\text { LC3 cellular content }\end{array}$ & $\begin{array}{l}\text { CTSB and uPAR regulate the } \\
\text { self-renewal properties of glioma } \\
\text { stem cells }\end{array}$ & Metastasis & & & \\
\hline CXCR 4 activation & High CXCR4 expression & SDF-1 $\alpha$-CXCR 4 signaling on & Promoted cancer cell survival & 67 & $\mathrm{NSC}$ & 3.64 \\
\hline CALN altivaliont & Increases autophagic activity & autophagy induction & under stress & & $1 \mathrm{NOC}$ & 3.04 \\
\hline FADD & $\begin{array}{l}\text { FADD is also implicated in cell } \\
\text { cycle progression, proliferation, } \\
\text { and tumorigenesis }\end{array}$ & $\begin{array}{l}\text { FADD in tumor progression } \\
\text { via Rheb-mTORC1 pathway in } \\
\text { breast cancer }\end{array}$ & $\begin{array}{l}\text { Atg5 contributes to autophagic } \\
\text { cell death by interacting with } \\
\text { (FADD) }\end{array}$ & 68,69 & 4.87 & 3.59 \\
\hline NFKB1 & $\begin{array}{l}\text { Increased activation of NF-kB } \\
\text { and MAPK via NFKB1 deletion } \\
\text { enhance macrophage and myofi- } \\
\text { broblast content at the repair }\end{array}$ & $\begin{array}{l}\text { Cross-talk between ER stress, } \\
\text { autophagy, apoptosis, and the }\end{array}$ & $\begin{array}{l}\text { NF- } \mathrm{KB} \text { inhibition partly } \\
\text { enhances the survival of cancer }\end{array}$ & $70-72$ & NSC & 5.84 \\
\hline & $\begin{array}{l}\text { Driving increased collagen } \\
\text { deposition and biomechanical } \\
\text { properties }\end{array}$ & fate of cancer cells & cells following BFA treatment & & & \\
\hline SNCA & $\begin{array}{l}\text { SNCA binds to (HMGB1) blocks } \\
\text { HMGB1-BECN1 binding, and } \\
\text { strengthens BECN1-BCL2 } \\
\text { binding }\end{array}$ & $\begin{array}{l}\text { Deregulation of these molecular } \\
\text { events by SNCA overexpression } \\
\text { leads to autophagy }\end{array}$ & Tumor survival & $73-75$ & NSC & 2.56 \\
\hline TGM2 & $\begin{array}{l}\text { Putative tumor suppressor in } \\
\text { the TP53 pathway and colony } \\
\text { formation }\end{array}$ & $\begin{array}{l}\text { Autophagy and CDKN1A- } \\
\text { mediated cell cycle arrest }\end{array}$ & Tumor suppressor & 76 & 2.96 & NSC \\
\hline
\end{tabular}




\begin{tabular}{|c|c|c|c|c|c|c|}
\hline \multirow[b]{2}{*}{ Gene expression changes } & \multirow[b]{2}{*}{ Cellular outcome } & \multirow[b]{2}{*}{ Effect(s) } & \multirow[b]{2}{*}{ Consequences on tumor fate } & \multirow[b]{2}{*}{ References } & \multicolumn{2}{|c|}{ Our study findings } \\
\hline & & & & & $43^{\circ} \mathrm{C}$ & $48^{\circ} \mathrm{C}$ \\
\hline \multirow[t]{2}{*}{ HGS } & $\begin{array}{l}\text { Critical role in the recycling } \\
\text { and degradation of membrane } \\
\text { receptors }\end{array}$ & \multirow{2}{*}{$\begin{array}{l}\text { Phosphorylation of SMAD1/5/8 } \\
\text { and TAK1/p38 to transduce } \\
\text { BMP signaling }\end{array}$} & \multirow[t]{2}{*}{ Tumor survival and invasion } & \multirow[t]{2}{*}{77,78} & \multirow[t]{2}{*}{2.76} & \multirow[t]{2}{*}{5.72} \\
\hline & $\begin{array}{l}\text { HGS-dependent TP53 exosome } \\
\text { formation }\end{array}$ & & & & & \\
\hline
\end{tabular}

Table 1. Autophagic genes involved in the tumorigenesis process VS our findings. Significant values are in bold. NSC non significant change.

dormancy. The findings are consistent with the results obtained from the study of genes involved in autophagy in this study, which finally can threaten the patients' lives in the clinic.

The most important finding in this study was the rethinking of the usage of autophagy inhibitors in the PTT therapeutic regimens. Colony formation assay findings as the outcome of PTT were shown that, despite the loss of a large number of cells at $48{ }^{\circ} \mathrm{C}$, cells can form colonies in the presence of autophagy inhibitor (Fig. 7A-E). It means that using autophagy inhibitors in lower temperatures can be beneficial, while in higher temperatures cause to exacerbate the fate of resistant tumor cells. It seems that a higher level of autophagy (e.g., EIF4E and eIF4G) and released factors from neurotic cells mutually evoked the invasion and metastasis-related signaling pathways at $48^{\circ} \mathrm{C}$ (Tables 1,3 ). For instance, it has been shown that the tumor formation process that arises from the Ras pathway activation requires high levels of autophagy for survival and cell proliferation ${ }^{3}$.

Since the use of hyperthermia to eliminate cancers has entered into the clinical phase, the results of this study allied to the others ${ }^{4}$ ring the alarms for all of us, which forcefully recommended using all necessary experiments to prevent unwanted complications. As shown in this study, after eradication of a large number of cancer cells at $48^{\circ} \mathrm{C}$, the remaining cells in the presence of an autophagy inhibitor will be able to form a tumor. This finding is in line with other scientists who have previously shown that even 100 cancer stem cells are enough to form a tumor $^{5}$. So, we strongly suggest further investigations to find the relationship between autophagic gene machinery and PTT-induced autophagy.

\section{Methods}

Materials. $\mathrm{HAuCl}_{4}, \mathrm{Hydroxychloroquine} \mathrm{(HCQ),} \mathrm{and} \mathrm{3-MA} \mathrm{were} \mathrm{obtained} \mathrm{from} \mathrm{Sigma-Aldrich} \mathrm{and} \mathrm{dis-}$ solved in deionized water to reach $100 \mathrm{mM}, 1 \mathrm{mM}$, and $100 \mathrm{mM}$ stock solutions, respectively. The antibodies used included LC3-II (Miltenyi Biotech, 130-090-853). Albumin, cetyltrimethylammonium bromide (CTAB), AgNo3, ascorbic acid, and $\mathrm{NaBH} 4$ were purchased from Sigma-Aldrich. The human neuroblastoma cell line SHSY5Y was obtained from the Stem Cell Research Center, Tabriz University of Medical Sciences. The high-glucose Dulbecco's Modified Eagle's Medium (DMEM/HG), fetal bovine serum (FBS), L-glutamine, 0.25\% TrypsinEDTA, and Penicillin/Streptomycin (Pen-Strep) were all purchased from Gibco. The Annexin-V-FLUOS Staining kit was purchased from Roche Company.

Characterization. UV-Vis spectra were recorded on a spectrophotometer (Cecil UV, UK). Transmission electron microscopy (TEM) analyses were performed by a Zeiss EM900 $80 \mathrm{kV}$ electron microscope. TEM samples were prepared by dropping a small quantity of dispersion onto formvar carbon 300 mesh thick grids. The size of AuNRs was determined by the dynamic light scattering (DLS) technique using Zetasizer Nano ZS90; Malvern Instruments, UK. The samples were irradiated with a laser model MDL-III-at a wavelength of $808 \mathrm{~nm}$ and the energy of $2.5 \mathrm{~W}$ (Changchun New Industries Optoelectronics Tech. Company). The dispersions' temperature was monitored using a digital thermometer with a thermocouple probe from Pyrometer Instrument Company. In the MTT assay, the absorbance (OD) of samples was measured at $570 \mathrm{~nm}$ using a microplate reader (BioTek, USA). Flow cytometry tests were performed on a flow cytometer (Partech space flow ${ }^{\circ}$ ), and data were analyzed by FlowJo software (version V.10).

Gold nanorods (AuNRs) synthesis. The synthesis of AuNRs was done according to the previously described seedless growth method ${ }^{26}$. Briefly, $5 \mathrm{~mL}$ of $1.0 \mathrm{mM} \mathrm{HAuCl}_{4}$ was added to $5 \mathrm{~mL}$ of $0.20 \mathrm{M} \mathrm{CTAB}$. Then, $250 \mathrm{~mL}$ of $4.0 \mathrm{mM} \mathrm{AgNO}_{3}$ was added, and the solution was gently shaken. By adding $8 \mathrm{~mL}$ of $37 \% \mathrm{HCl} \mathrm{pH}$ of the solution was adjusted to $1-1.15$. Subsequently, $70 \mathrm{~mL}$ ascorbic acid $(78.8 \mathrm{mM})$ was added to the solution then gently shaking until the solution was clear. After that, $15 \mathrm{~mL}$ of $0.01 \mathrm{M}$ ice-cold $\mathrm{NaBH}_{4}$ was injected to the unstirred growth solution and allowed to react for $6 \mathrm{~h}$. The solution was centrifuged at 10,000 rpm for $15 \mathrm{~min}$, and the supernatant was removed. The pellet was suspended in water and centrifuged at the same speed for an additional $15 \mathrm{~min}$.

Surface modification of AuNRs with BSA (BSA-AuNRs). BSA was used to modify the surface of the AuNRs according to a method described by Tebbe et al. ${ }^{48}$. Briefly, the NP dispersions were diluted with deionized water and slowly added to the BSA solution under ultrasonication (BSA solution/NP dispersions, 1:1 $\mathrm{v} / \mathrm{v})$. The BSA solution contains BSA $(10 \mathrm{mg} / \mathrm{mL})$, and $0.02 \%$ citrate and $\mathrm{pH}$ were adjusted to 7 . The NPs were sonicated for $30 \mathrm{~min}$ and then centrifuged at $6500 \mathrm{rpm}$ for $6 \mathrm{~min}$ followed by replacement of supernatant with 10X-diluted BSA solution ( $1 \mathrm{mg} / \mathrm{ml}, \mathrm{pH}=12,0.02 \%$ citrate). The final solution was stirred for at least $24 \mathrm{~h}$. Eventually, the particles were centrifuged and washed with deionized water before use. 


\begin{tabular}{|c|c|c|c|c|c|c|}
\hline \multirow[b]{2}{*}{ Gene expression changes } & \multirow[b]{2}{*}{ Cellular outcome } & \multirow[b]{2}{*}{ Effect(s) } & \multirow[b]{2}{*}{ Consequences on tumor fate } & \multirow[b]{2}{*}{ References } & \multicolumn{2}{|c|}{$\begin{array}{l}\text { Our study } \\
\text { findings }\end{array}$} \\
\hline & & & & & $43^{\circ} \mathrm{C}$ & $48^{\circ} \mathrm{C}$ \\
\hline \multirow{2}{*}{ ATG5 and ATG7- RAS } & \multirow{2}{*}{ Increased autophagy } & \multirow{2}{*}{ Mitochondria activation } & \multirow{2}{*}{ Tumor formation } & \multirow{2}{*}{4,43} & 2.63 & 2.94 \\
\hline & & & & & 2.17 & NSC \\
\hline ATG16L1 & \multirow{3}{*}{ Autophagy deficiency } & Oxidative stress & \multirow{3}{*}{ Tumor suppression } & \multirow{3}{*}{79,80} & 1346.5 & 1164.1 \\
\hline \multirow{2}{*}{ LC3-II degradation } & & Damaged mitochondria & & & 1346.5 & 1164.1 \\
\hline & & Inflammation induction $(1 \beta$, IL-18) & & & 2.05 & 4.58 \\
\hline Autophagy activation & p27Kip1 coaded by CDKN1B & CDK-dependent kinase inhibitor & Tumor promotion & 81 & 423.14 & 134.83 \\
\hline \multirow{2}{*}{ Autophagy deactivation } & \multirow{2}{*}{ ATG3/7/p62 targeting } & \multirow{2}{*}{ Pfkfb3 normal expression } & \multirow{2}{*}{ Tumor re-proliferation } & \multirow{2}{*}{82} & NSC & NSC \\
\hline & & & & & 2.17 & NSC \\
\hline \multirow{3}{*}{ STAT1 inhibition } & \multirow{3}{*}{$\begin{array}{l}\text { p27 (CDKN1B), p21(CDKN1A) } \\
\text { upregulation }\end{array}$} & $\begin{array}{l}\text { Increase in IDO1 and Kyn recep- } \\
\text { tors }\end{array}$ & Tumor dormancy & \multirow{3}{*}{83} & & \\
\hline & & \begin{tabular}{|l|} 
Rb hypophosphorylation \\
\end{tabular} & Increase in colony formation & & 423.1 & 134.8 \\
\hline & & $\begin{array}{l}\text { Suppress E2F transcription factor } \\
\text { activity }\end{array}$ & Decrease in proliferation & & & \\
\hline AMBRAl & $\begin{array}{l}\text { AMBRA1 role in the modulation } \\
\text { of C-MYC phosphorylation and } \\
\text { stability }\end{array}$ & $\begin{array}{l}\text { Intracellular switch between } \\
\text { autophagy and apoptosis }\end{array}$ & Colony formation & 84,85 & NSC & 2.05 \\
\hline ATG9B mutation & Autophagy suppression & $\begin{array}{l}\text { Blocked recruitment of p62-asso- } \\
\text { ciated ubiquitinated protein } \\
\text { for autophagosome-lysosome } \\
\text { degradation }\end{array}$ & Tumorigenesis & 64,86 & 2.44 & 4.07 \\
\hline GABARAPL1 down-regulation & $\begin{array}{l}\text { Disruption of the intracellular } \\
\text { transport of receptors and the } \\
\text { autophagy pathway }\end{array}$ & $\begin{array}{l}\text { Low GABARAPL1 expression } \\
\text { was correlated with a high risk of } \\
\text { metastasis }\end{array}$ & Metastasis & 87 & 2.04 & NSC \\
\hline ATG10 up-regulation & $\begin{array}{l}\text { Acts as an E2-like enzyme that cata- } \\
\text { lyzes the conjugation of ATG12 to } \\
\text { ATG5 and increased autophagy }\end{array}$ & Lymphovascular invasion & Metastasis & 88 & 2.27 & 5.05 \\
\hline RAB24 over-expression & $\begin{array}{l}\text { Promote the EMT, adhesion and } \\
\text { vasculogenic effects }\end{array}$ & Promotes the malignant phenotype & $\begin{array}{l}\text { Tumor growth, metastasis, EMT } \\
\text { activation }\end{array}$ & 88 & 2.76 & 2.23 \\
\hline ATG5 frameshift mutations & $\begin{array}{l}\text { Features of cancers with microsatel- } \\
\text { lite instability (MSI) }\end{array}$ & $\begin{array}{l}\text { Common in gastric and colorectal } \\
\text { carcinomas }\end{array}$ & $\begin{array}{l}\text { Tumor development by autophagy } \\
\text { deregulation }\end{array}$ & 64 & 2.63 & 2.94 \\
\hline CTSB & Dormancy bub gene & Strong biomarker for GBM patient's & Tumor progression & 89 & 10.98 & 9.68 \\
\hline & & survival & Metastasis & & & \\
\hline & Independent prognostic factor for & Increases autophagic activity and & Survival & & & \\
\hline CXCR4 activation & disease relapse and survival in acute & decreases & Colony formation & 67,90 & NSC & 3.64 \\
\hline & myeloid leukemia (AML) patients & Cytarabine-induced apoptosis & Proliferation & & & \\
\hline IGF- 1 activation & Activated protein kinase B (AKT) & Inhibit autophagy & $\begin{array}{l}\text { Induce apoptosis in drug resistant } \\
\text { cells }\end{array}$ & 91,92 & 2.80 & 2.05 \\
\hline INS over-expression & Precursor of insulin & $\begin{array}{l}\text { Insulin signaling and the regulation } \\
\text { of autophagy are relevant to neuro- } \\
\text { degenerative disorders }\end{array}$ & Survival & 93 & 7.81 & 15.51 \\
\hline MAPVE & Integration point of proliferation, & Indispensable for TNF superfamily & Tumor promotion & 94 & 206 & NISC \\
\hline MAPK8 & $\begin{array}{l}\text { difterentiation, transcription regu- } \\
\text { lation and development }\end{array}$ & 10 (TNFSF)-induced autophagy & Survival & Pet & 2.96 & NSC \\
\hline PIK3CG & Catalytic subunit of class I PI3Ks & $\begin{array}{l}\text { Up-regulated under stress condi- } \\
\text { tions }\end{array}$ & Cell remodeling and tissue failure & 95 & 9.42 & 71.92 \\
\hline & & & Survival promoting autophagy & & & \\
\hline MAPK14 & $\begin{array}{l}\text { Activation of MAPK14 impairs } \\
\text { autophagosome-lysosome fusion }\end{array}$ & $\begin{array}{l}\text { Phosphorylates ATG5 at threonine } \\
75\end{array}$ & Cell proliferation & 96,97 & 2.05 & 2.23 \\
\hline & & & Migration, Resistance to apoptosis & & & \\
\hline & & & Promote protein synthesis & & & \\
\hline RPS6KB1 & In response to mTOR & Autophagy inhibition & Cell growth & 98 & NSC & 2.08 \\
\hline & & & Cell proliferation & & & \\
\hline & & & Metastasis & & & \\
\hline DRAM? & Is a lycosomal protein & $\begin{array}{l}\text { DRAM2 overexpression induced } \\
\text { cell migration proteins including }\end{array}$ & Proliferation & 99,100 & 205 & $\mathrm{NSC}$ \\
\hline DNATIL & is a lysosonital piterente & $\begin{array}{l}\text { RAC1, RHOA, RHOC, ROCK1, } \\
\text { and decreased RHOB expression }\end{array}$ & Migration & & 2.00 & Nou \\
\hline & & & Cell cycle activation & & & \\
\hline & & & Cell proliferation & & & \\
\hline LAMP1 & LAMP1 is lysosomal marker & the antitumor effects of UBL4A in & Migration & 101,102 & 3.64 & 3.08 \\
\hline & & & Invasion & & & \\
\hline & Key regulator of protein synthesis & & Autophagy inhibition & & & \\
\hline mTOR & via $4 \mathrm{EBP} 1$ and $\mathrm{p} 70 \mathrm{~S} 6 \mathrm{~K} 1 / 2$ phos- & $\begin{array}{l}\text { Increases the translational capacity } \\
\text { of cancer cells }\end{array}$ & Dormancy & 103 & 6.04 & 6.48 \\
\hline & phorylation & & Metastasis & & & \\
\hline
\end{tabular}




\begin{tabular}{|c|c|c|c|c|c|c|}
\hline \multirow[b]{2}{*}{ Gene expression changes } & \multirow[b]{2}{*}{ Cellular outcome } & \multirow[b]{2}{*}{ Effect(s) } & \multirow[b]{2}{*}{ Consequences on tumor fate } & \multirow[b]{2}{*}{ References } & \multicolumn{2}{|c|}{$\begin{array}{l}\text { Our study } \\
\text { findings }\end{array}$} \\
\hline & & & & & $43^{\circ} \mathrm{C}$ & $48^{\circ} \mathrm{C}$ \\
\hline \multirow{3}{*}{ RPLP0 } & \multirow{3}{*}{$\begin{array}{l}\text { Belongs to the L10P family of } \\
\text { ribosomal proteins }\end{array}$} & Affected p21 expression & Cell promotion & \multirow{3}{*}{104,105} & \multirow{3}{*}{ NSC } & \multirow{3}{*}{619.5} \\
\hline & & Induction & \multirow{2}{*}{$\begin{array}{l}\text { Autophagy induction (Survival) in } \\
\text { response to RPLP deficiency stress }\end{array}$} & & & \\
\hline & & G1 arrest of gastric cancer cells & & & & \\
\hline \multirow{2}{*}{ CTSS } & \multirow{2}{*}{$\begin{array}{l}\text { Is a lysosomal cysteine protease that } \\
\text { may participate in the degradation } \\
\text { of antigenic proteins }\end{array}$} & \multirow{2}{*}{$\begin{array}{l}\text { Cleaves some extracellular matrix } \\
(\mathrm{ECM}) \text { proteins }\end{array}$} & Tumorigenesis stimulation & \multirow{2}{*}{106,107} & \multirow{2}{*}{11.35} & \multirow{2}{*}{ NSC } \\
\hline & & & Metastasis & & & \\
\hline \multirow{2}{*}{ ESR1 } & \multirow{2}{*}{$\begin{array}{l}\text { Point mutations on ESR1 are driv- } \\
\text { ers for resistance, and promote of } \\
\text { ER } \alpha \text { without the bound ligand }\end{array}$} & \multirow{2}{*}{$\begin{array}{l}\text { Ligand independently ER stimula- } \\
\text { tion }\end{array}$} & Proliferation & \multirow{2}{*}{108,109} & \multirow{2}{*}{9.68} & \multirow{2}{*}{4.16} \\
\hline & & & Long-distance metastasis & & & \\
\hline \multirow{3}{*}{ Autophagy manipulation } & \multirow{3}{*}{ eIF4E/eIF4GI knockdown } & \multirow{3}{*}{$\begin{array}{l}\text { The decrease in ERa, SMAD5, } \\
\text { NFkB, CyclinD1, c-MYC, and } \\
\text { HIFla }\end{array}$} & The decrease in EMT promoter & \multirow{3}{*}{59} & \multirow{3}{*}{1049.1} & \multirow{3}{*}{1904} \\
\hline & & & Increase in EMT inhibitors & & & \\
\hline & & & $\begin{array}{l}\text { The decrease in migration capabil- } \\
\text { ity }\end{array}$ & & & \\
\hline
\end{tabular}

Table 2. Autophagic genes involved in invasion (colonization, proliferation, tumor formation, promotion, metastasis) VS our findings. Significant values are in bold. NSC non significant change.

Temperature elevation modeling. After determining the cellular uptake rate of nanoparticles, to simulate the uptaken nanoparticles' ability to increase the ambient temperature, we dissolved the same amount of BSA-AuNRs in deionized water and irradiated with 808-nm continuous-wave NIR laser at different power densities. The temperature of samples was monitored using a digital thermometer with a thermocouple probe.

Cell culture. The human neuroblastoma cell line, SH-SY5Y cells, were cultured in DMEM/HG supplemented with $10 \%$ FBS and $1 \%$ Pen-Strep. The culture flasks were maintained at $37{ }^{\circ} \mathrm{C}$ under $5 \% \mathrm{CO}_{2}$ under a humidified atmosphere. Cells at passages 3 to 6 were used in this study. The cells were sub-cultured using $0.25 \%$ Trypsin-EDTA solution.

Analyzing cellular uptake of AuNRs using atomic absorption spectroscopy (AAS). SH-SY5Y cells were seeded in 6-well plates with at an initial cell density of $2 \times 10^{5}$ cells/well. After reaching 70-80\% confluence, the culture medium was replaced with fresh medium containing $30 \mathrm{ppm}$ BSA-AuNRs and $2 \%$ FBS. The culture medium was discarded after a 4 -h incubation period. Then, the cells collected using an enzymatic solution (Trypsin-EDTA) dissolved in Aqua Regia overnight and heated to about $140^{\circ} \mathrm{C}$ to excluding hydrogen chloride and nitrogen oxides until the solution became colorless and clear ${ }^{49}$. After that, the digested solution incubated in an aqueous solution containing $2 \%$ nitric acid and $1 \%$ hydrogen chloride for loosing and detaching gold atoms in nanoparticle lattice; the total cellular gold content was determined by AAS.

AuNR-mediated PTT protocol in vitro. In this study, SH-SY5Y cells were randomly allocated into three different groups as follows: Control, $30 \mathrm{ppm}$ BSA-AuNRs $\left(43^{\circ} \mathrm{C}\right)$, and $30 \mathrm{ppm} \mathrm{BSA-AuNRs}\left(48^{\circ} \mathrm{C}\right)$. In this regard, cells were maintained for $4 \mathrm{~h}$, followed by replacement with BSA-AuNR free culture medium. Then, cells were irradiated by an 808-nm NIR laser at a power density of 0.3 and $0.9 \mathrm{~W}$ for 8 min (to reaching the $43{ }^{\circ} \mathrm{C}$ and $48^{\circ} \mathrm{C}$ ) in the absence and presence of $10 \mu \mathrm{M}$ HCQ. During laser irradiation, the temperature of the culture medium was carefully monitored.

MTT assay. The localized cell-killing ability of PTT at the varied densities ( 0.3 and $0.9 \mathrm{~W})$ was assessed by a typical MTT assay. After irradiation, cells were maintained for the next $24 \mathrm{~h}$, and the survival rate was measured by using a standard MTT assay. To this end, the culture medium was discarded, replaced with $5 \mathrm{mg} / \mathrm{ml} \mathrm{MTT}$ solution, and incubated at $37^{\circ} \mathrm{C}$ for $3-4 \mathrm{~h}$. Thereafter, the supernatants were removed, and $100 \mu \mathrm{DMSO}$ solution was added to each well to dissolve formazan crystals. Percent of cell viability was denoted as the relative absorbance of treated versus untreated viable cells. The following formula was used to calculate the inhibition of cell growth:

Cell viability $(\%)=($ mean of the absolute value of treatment group/mean of the absolute value of control $) \times 100 \%$.

Flow cytometric analysis of apoptotic cells. To quantify the effect of PTT at varied energy densities on SH-SY5Y cells, we performed flow cytometry analysis. To this end, cells were cultured in each well of 24-well plates and irradiated as above-mentioned. Twenty-four hours post-PTT, cells were harvested, permeabilized, and stained using the Annexin-V-BioXBio Staining kit according to the manufacturer's instructions. The percent of alive, apoptotic, and necrotic cells were analyzed by the Partech Cyflow space Flow cytometry system. The raw data were processed using FlowJo software (version V.10).

Monitoring autophagy status using flow cytometry and immunofluorescence staining. Flow cytometry analysis. To assess autophagy status after PTT, the SH-SY5Y cells were incubated with the FITC- 


\begin{tabular}{|c|c|c|c|c|c|c|}
\hline \multirow[b]{2}{*}{ Gene expression changes } & \multirow[b]{2}{*}{ Cellular outcome } & \multirow[b]{2}{*}{ Effect(s) } & \multirow[b]{2}{*}{ Consequences on tumor fate } & \multirow[b]{2}{*}{ References } & \multicolumn{2}{|c|}{ Our study findings } \\
\hline & & & & & $43^{\circ} \mathrm{C}$ & $48^{\circ} \mathrm{C}$ \\
\hline \multirow{2}{*}{ Dormancy activation } & \multirow{2}{*}{$\begin{array}{l}\text { P53 overexpression induced by } \\
\text { Cdknlb }\end{array}$} & $\begin{array}{l}\text { Pentose phosphate pathway } \\
\text { destruction }\end{array}$ & Cell death & \multirow[t]{2}{*}{110} & \multirow{2}{*}{3.24} & \multirow{2}{*}{ NSC } \\
\hline & & Increased ROS & Dormancy induction by IFN-b & & & \\
\hline \multirow{3}{*}{$\begin{array}{l}\text { FasL (CD95L or CD178), TRAIL } \\
\text { and TNF- } \alpha \text { activation }\end{array}$} & \multirow{3}{*}{ DISC formation } & Caspase- 3,6 and 7 activation & Directly cell death & \multirow{3}{*}{111} & 408.7 & 151.6 \\
\hline & & \multirow{2}{*}{ Bid change into tBid } & \multirow{2}{*}{$\begin{array}{l}\text { Mitochondria dependent apop- } \\
\text { totic cell death }\end{array}$} & & 4.07 & -4.10 \\
\hline & & & & & 4.10 & -2.90 \\
\hline \multirow{3}{*}{ Autophagy inhibition } & \multirow{3}{*}{ ATG7 depletion } & $\begin{array}{l}\text { Accumulation of damaged mito- } \\
\text { chondria }\end{array}$ & The killing of dormant cells & \multirow{3}{*}{112} & \multirow{3}{*}{2.17} & \multirow{3}{*}{ NSC } \\
\hline & & Increase of ROS & Does not affect cell metastasis and & & & \\
\hline & & Increase of apoptosis & proliferation & & & \\
\hline \multirow{3}{*}{ Autophagy activation } & \multirow{3}{*}{ TMEM166 overexpression } & High LC3II/LC3I & \multirow{3}{*}{$\begin{array}{l}\text { Autophagy and apoptosis regula- } \\
\text { tor (autophagic and apoptotic cell } \\
\text { death) }\end{array}$} & \multirow{3}{*}{113} & \multirow{3}{*}{2.27} & \multirow{3}{*}{295.1} \\
\hline & & Vacuolization & & & & \\
\hline & & $\begin{array}{l}\text { Mitochondria membrane permea- } \\
\text { bilization }\end{array}$ & & & & \\
\hline GABARAPL2/ULK upregulation & $\begin{array}{l}\text { Necessary to maturation of two } \\
\text { layers membranous vesicles }\end{array}$ & $\begin{array}{l}\text { Shrinkage of tumor volume in } \\
\text { complex with ULK2 }\end{array}$ & Apoptotic cancer cell death & 114 & 3.22 & 2.12 \\
\hline IRGM KO & p47 dependent GTPase & $\begin{array}{l}\text { Negative regulation of IFN } \\
\text { signaling }\end{array}$ & Inhibition of autophagic cell death & 115 & 46.37 & NSC \\
\hline \multirow{2}{*}{ ATG16L2 } & \multirow{2}{*}{ Methylation of ATG16L2 } & \multirow{2}{*}{ Downregulation of autophagy } & Autophagic cancer cell death & \multirow{2}{*}{116,117} & \multirow{2}{*}{29.55} & 2163 \\
\hline & & & \begin{tabular}{|l|} 
Patients survival \\
\end{tabular} & & & 2.03 \\
\hline Inherent ATG5 or autophagy KO & Autophagy deficiency & - & Increase apoptotic cell death & 118 & 2.63 & 2.94 \\
\hline Increase of Bax and Bak1 & $\begin{array}{l}\text { Intrinsic pathway of apoptosis } \\
\text { (mitochondria) }\end{array}$ & $\begin{array}{l}\text { Indirectly effect on autophagy by } \\
\text { inactivation of BaK1 and Bax }\end{array}$ & Increase cancer cell apoptosis & 119,120 & 492.85 & 299.21 \\
\hline Bid and PUMA (apoptosis-associ- & \begin{tabular}{|l|} 
BID acts as molecular link \\
between apoptosis and autophagy
\end{tabular} & $\begin{array}{l}\text { Contribute to identifying the } \\
\text { molecular mechanism by which }\end{array}$ & & 66,121 & 3.35 & 2.42 \\
\hline ated genes) & $\begin{array}{l}\text { PUMA is certain substrate for } \\
\text { CMA }\end{array}$ & $\begin{array}{l}\text { molecular mechanism by which } \\
\text { autophagy drives cells to death }\end{array}$ & Autophagic cell death & $0,0,21$ & 3.35 & 2.42 \\
\hline & One of the most important genes & & Tumor suppressor & 65 & & \\
\hline DAPK1 & $\begin{array}{l}\text { in intra/extra cellular apoptotic } \\
\text { pathways }\end{array}$ & ARHI dependent & Apoptotic cell death & 63 & 2280.29 & 1453.18 \\
\hline PTEN & $\begin{array}{l}\text { Negative regulator of PI3K/AKT/ } \\
\text { mTORC1 }\end{array}$ & $\begin{array}{l}\text { Autophagy activation, PI3K/Akt } \\
\text { inhibition, PI3K/AKT/mTORC1 } \\
\text { inhibition }\end{array}$ & Tumor suppressor & 47 & 35.38 & 23.02 \\
\hline PTEN & $\begin{array}{l}\text { Indirectly positive autophagy } \\
\text { regulator }\end{array}$ & $\begin{array}{l}\text { PTEN inhibitors (Tsc1 or Tsc2, } \\
\text { p27) and Foxo3a }\end{array}$ & Escape from dormancy & 122 & 35.38 & 23.02 \\
\hline PTEN & Tumor suppressor & $\begin{array}{l}\text { Apoptosis modulators DRAM, } \\
\text { DAPk and DRP-1, PTEN, E93, } \\
\text { Akt/PKB, and mTOR), Bcl-2 fam- } \\
\text { ily proteins, TRAIL and beclin } 1\end{array}$ & $\begin{array}{l}\text { Autophagy act as upstream con- } \\
\text { trol of apoptosis death }\end{array}$ & 113 & 35.38 & 23.02 \\
\hline GAA deficiency & $\begin{array}{l}\text { Lysosomal hydrolysis of glycogen } \\
\text { to glucose (glycogen storage } \\
\text { disease II, or Pompe) }\end{array}$ & $\begin{array}{l}\text { Accumulation of abnormal } \\
\text { proteins and organelles due to } \\
\text { inhibition of autophagy }\end{array}$ & Cell death & 123 & NSC & 3.69 \\
\hline Autophagy abortion & DRAM1 overexpression & By p53 & Apoptotic death & 124 & 4.36 & 2.65 \\
\hline
\end{tabular}

Table 3. Autophagic genes involved in cell death (autophagic or apoptotic) VS our findings. Significant values are in bold. NSC non significant change.

conjugated LC3 antibody. Twenty-four hours after PTT, cells were collected from different groups, washed twice with PBS, and fixed using pre-cooled 3.7\% paraformaldehyde for $8 \mathrm{~min}$. By using the permeabilization buffer, cells were permeabilized and blocked with $1 \%$ BSA. Then, cells were incubated in a solution containing a diluted FITC-conjugated LC3 (1:200) antibody overnight. After twice PBS washes, cells were incubated with DyLight 488 conjugated secondary antibody (1:500) for $1 \mathrm{~h}$. Finally, the samples were analyzed by Partech Cyflow space flow cytometry and FlowJo software (version V.10).

Immunofluorescence imaging. Cells $\left(1 \times 10^{4}\right)$ were seeded in each well of 8 -well Chambered Cell Culture Slide (SPL) and cultured until reaching 70-80\% confluency. Here, the cells were classified into Control and AuNRs groups. In the AuNRs group, cells were exposed to 808-nm laser with different energy densities of 0.3 and $0.9 \mathrm{~W}$ for 8 min to reach temperatures of $43^{\circ} \mathrm{C}$ and $48^{\circ} \mathrm{C}$. After $12 \mathrm{~h}$, cells were washed with PBS and fixed with $3.7 \%$ paraformaldehyde for $10 \mathrm{~min}$. Fixed cells were permeabilized with permeabilization buffer for $15 \mathrm{~min}$, blocked with $1 \%$ BSA for $60 \mathrm{~min}$, and incubated with anti-LC3 antibodies (1:200) overnight. After washing with PBS, cells were incubated for $1 \mathrm{~h}$ with DyLight 488 conjugated secondary antibody (1:500). Finally, cells were evaluated under a fluorescence microscope (Olympus microscope Bh2-RFCA, Japan). The images were analyzed using the Leica Application Suite 2.02 software. 
PCR Profiler array analysis of various gene expression related to autophagy. The Human Custom RT2 Profiler ${ }^{\mathrm{mt}}$ PCR Array (CAPH11870A, Qiagen) profiles the expression of 84 genes involved autophagy. RNA was purified using the Qiagen RNAse kit, including on-column DNAse treatment to remove genomic DNA. cDNA was prepared with the RT2 First Strand Kit (SA Biosciences, Frederick, Maryland, USA). A PCR profiler array was performed (RT2 SYBR Green/ROX qPCR Master Mix; SA Biosciences) in 96-well plates on an ABI 7300 instrument (Applied Biosystems, California, USA). For data analysis, the $\Delta \Delta \mathrm{Ct}$ method was applied using the RT2 Profiler PCR Array software package, and statistical analyses performed $(n=3)$. This package uses $\Delta \Delta$ CT-based fold change calculations and the Student's $t$ test to calculate two-tail, equal variance P-values. The fold changes were calculated using the equation $2^{-\Delta \Delta C t}$. If fold change was greater than 1 , the result was considered as fold up-regulation. If fold change was less than 1 , the negative inverse of the result was considered as fold down-regulation ${ }^{34}$.

Spheroid-formation assay. The possible effect of BSA-AuNR-mediated PTT was investigated on the clonogenicity property of SH-SY5Y cells. In brief, cells were exposed to 808-nm NIR laser and collected using the enzymatic solution. Thereafter, 1000 cells from the abovementioned groups were resuspended in a solution containing $0.1 \%$ agar, $1 \%$ gelatin, and $2.5 \%$ methylcellulose and transferred into each well of 6 -well plates in the presence and absence of $10 \mu \mathrm{M}$ HCQ. The plates were kept for 21 days, and the number of colonies was calculated per each well. This assay was done in triplicate.

Monitoring the levels of LC3, P62, and Ki67 using ELISA. After completion of laser irradiation, cells were collected and lyzed using protein lysis buffer $(50 \mathrm{mM} \mathrm{NaCl}, 0.1 \%$ SDS, $50 \mathrm{mM}$ Tris-HCl, 2 mM EDTA, $1 \% \mathrm{NP}-40$ ). The samples were centrifuged at $14,000 \mathrm{rpm}$ at $4{ }^{\circ} \mathrm{C}$, supernatants collected and stored at $-20{ }^{\circ} \mathrm{C}$ until use. To perform ELISA assay, $1 \mu \mathrm{g} / \mathrm{ml}$ of P62 (Abcam), LC3 (Abcam), and Ki67 (Abcam) antibodies were poured in each well of 96 -well polystyrene plates and incubated at $4{ }^{\circ} \mathrm{C}$ overnight. The next day, supernatants were discarded, and wells were blocked using $1 \%$ BSA solution at room temperature for $30 \mathrm{~min}$. We added $1 \mu \mathrm{g} /$ $\mathrm{ml}$ of protein from different groups and plates were incubated for $1 \mathrm{~h}$ at room temperature. After twice PBS wash, HRP-conjugated secondary antibody was added to each well and maintained at room temperature for $1 \mathrm{~h}$. Following PBS wash, 3, 3'-Diaminobenzidine (DAB) was added, and the reaction stopped using $5 \% \mathrm{H}_{2} \mathrm{SO}_{4}$. Finally, the OD was read at $450 \mathrm{~nm}$ using a microplate reader.

Statistical analysis. Data were presented as mean \pm SD. For the comparison of multiple groups, One-Way ANOVA and Tukey post hoc was used. P values $<0.05$ were considered statistically significant. All experiments were done in triplicate otherwise mentioned.

Received: 7 January 2021; Accepted: 22 November 2021

Published online: 14 December 2021

\section{References}

1. Bani, F. et al. Graphene-polyglycerol-curcumin hybrid as a near-infrared (NIR) laser stimuli-responsive system for chemophotothermal cancer therapy. RSC Adv. 6(66), 61141-61149 (2016).

2. Huang, X. et al. Determination of the minimum temperature required for selective photothermal destruction of cancer cells with the use of immunotargeted gold nanoparticles. Photochem. Photobiol. 82(2), 412-417 (2006).

3. Zhang, Y. et al. Temperature-dependent cell death patterns induced by functionalized gold nanoparticle photothermal therapy in melanoma cells. Sci. Rep. 8(1), 8720 (2018).

4. Pattani, V. P. et al. Role of apoptosis and necrosis in cell death induced by nanoparticle-mediated photothermal therapy. J. Nanopart. Res. 17(1), 20 (2015).

5. Hanahan, D. \& Weinberg, R. A. Hallmarks of cancer: The next generation. Cell 144(5), 646-674 (2011).

6. Wei, M.-F. et al. Autophagy promotes resistance to photodynamic therapy-induced apoptosis selectively in colorectal cancer stem-like cells. Autophagy 10(7), 1179-1192 (2014).

7. Sui, X. et al. Autophagy and chemotherapy resistance: A promising therapeutic target for cancer treatment. Cell Death Dis. 4(10), e838 (2013).

8. Ou, Y.-C. et al. Gold nanoantenna-mediated photothermal drug delivery from thermosensitive liposomes in breast cancer. ACS Omega 1(2), 234-243 (2016).

9. Janku, F. et al. Autophagy as a target for anticancer therapy. Nat. Rev. Clin. Oncol. 8(9), 528 (2011).

10. Dikic, I. \& Elazar, Z. Mechanism and medical implications of mammalian autophagy. Nat. Rev. Mol. Cell Biol. 19, 349-364 (2018).

11. Mizushima, N. et al. Autophagy fights disease through cellular self-digestion. Nature 451(7182), 1069 (2008).

12. Ogier-Denis, E. \& Codogno, P. Autophagy: A barrier or an adaptive response to cancer. Biochim. Biophys. Acta (BBA) Rev. Cancer 1603(2), 113-128 (2003).

13. Lu, Z. et al. The tumor suppressor gene ARHI regulates autophagy and tumor dormancy in human ovarian cancer cells. J. Clin. Investig. 118(12), 3917-3929 (2008).

14. Ogier-Denis, E. \& Codogno, P. Autophagy: A barrier or an adaptive response to cancer. Biochim. Biophys. Acta 1603(2), 113-128 (2003).

15. Klionsky, D. J. Autophagy: From phenomenology to molecular understanding in less than a decade. Nat. Rev. Mol. Cell Biol. 8(11), 931-937 (2007).

16. Barkan, D. et al. Inhibition of metastatic outgrowth from single dormant tumor cells by targeting the cytoskeleton. Cancer Res. 68(15), 6241-6250 (2008).

17. Ali, M. R. et al. Targeting heat shock protein 70 using gold nanorods enhances cancer cell apoptosis in low dose plasmonic photothermal therapy. Biomaterials 102, 1-8 (2016).

18. Ali, M. R. et al. Treatment of natural mammary gland tumors in canines and felines using gold nanorods-assisted plasmonic photothermal therapy to induce tumor apoptosis. Int. J. Nanomed. 11, 4849 (2016). 
19. Obara, K. et al. Insufficient radiofrequency ablation therapy may induce further malignant transformation of hepatocellular carcinoma. Hepatol. Int. 2(1), 116-123 (2008).

20. Mouratidis, P. X., Rivens, I. \& Ter Haar, G. A study of thermal dose-induced autophagy, apoptosis and necroptosis in colon cancer cells. Int. J. Hyperthermia 31(5), 476-488 (2015).

21. Pérez-Hernández, M. et al. Dissecting the molecular mechanism of apoptosis during photothermal therapy using gold nanoprisms. ACS Nano 9(1), 52-61 (2014).

22. Tong, L. et al. Gold nanorods mediate tumor cell death by compromising membrane integrity. Adv. Mater. 19(20), 3136-3141 (2007).

23. Aioub, M. \& El-Sayed, M. A. A real-time surface enhanced raman spectroscopy study of plasmonic photothermal cell death using targeted gold nanoparticles. J. Am. Chem. Soc. 138(4), 1258-1264 (2016).

24. Zhang, M. et al. Near-infrared photothermal therapy using EGFR-targeted gold nanoparticles increases autophagic cell death in breast cancer. J. Photochem. Photobiol. B 170, 58-64 (2017).

25. Abadeer, N. S. \& Murphy, C. J. Recent progress in cancer thermal therapy using gold nanoparticles. J. Phys. Chem. C 120(9), 4691-4716 (2016).

26. Ali, M. R., Snyder, B. \& El-Sayed, M. A. Synthesis and optical properties of small Au nanorods using a seedless growth technique. Langmuir 28(25), 9807-9815 (2012).

27. Zeinvand-Lorestani, M. et al. Autophagy upregulation as a possible mechanism of arsenic induced diabetes. Sci. Rep. 8(1), 1-15 (2018).

28. Kaushik, S., Singh, R. \& Cuervo, A. M. Autophagic pathways and metabolic stress. Diabetes Obes. Metab. 12, 4-14 (2010).

29. He, C. \& Klionsky, D. J. Regulation mechanisms and signaling pathways of autophagy. Annu. Rev. Genet. 43, 67-93 (2009).

30. Cuervo, A. M. Autophagy: Many paths to the same end. Mol. Cell. Biochem. 263(1), 55-72 (2004).

31. Kanehisa, M. et al. KEGG as a reference resource for gene and protein annotation. Nucleic Acids Res. 44(D1), D457-D462 (2016).

32. Kanehisa, M. et al. KEGG: new perspectives on genomes, pathways, diseases and drugs. Nucleic Acids Res. 45(D1), D353-D361 (2017).

33. Nixon, R. A. \& Yang, D.-S. Autophagy and neuronal cell death in neurological disorders. Cold Spring Harbor Perspect. Biol. 4(10), a008839 (2012).

34. Saitoh, T. \& Akira, S. Regulation of innate immune responses by autophagy-related proteins. J. Cell Biol. 189(6), 925-935 (2010).

35. Wu, H. et al. Crosstalk between macroautophagy and chaperone-mediated autophagy: Implications for the treatment of neurological diseases. Mol. Neurobiol. 52(3), 1284-1296 (2015).

36. Tanida, I. et al. The FAP motif within human ATG7, an autophagy-related E1-like enzyme, is essential for the E2-substrate reaction of LC3 lipidation. Autophagy 8(1), 88-97 (2012)

37. Poillet-Perez, L. et al. Interplay between ROS and autophagy in cancer cells, from tumor initiation to cancer therapy. Redox Biol. 4, 184-192 (2015).

38. Kaliszczak, M. et al. The HDAC6 inhibitor C1A modulates autophagy substrates in diverse cancer cells and induces cell death. Br. J. Cancer 119(10), 1278-1287 (2018).

39. Yin, Z., Pascual, C. \& Klionsky, D. J. Autophagy: Machinery and regulation. Microb. Cell 3(12), 588 (2016).

40. Wirawan, E. et al. Autophagy: For better or for worse. Cell Res. 22(1), 43-61 (2012).

41. Li, W., Yang, Q. \& Mao, Z. Chaperone-mediated autophagy: Machinery, regulation and biological consequences. Cell. Mol. Life Sci. 68(5), 749-763 (2011).

42. Elgendy, M. et al. Oncogenic Ras-induced expression of Noxa and Beclin-1 promotes autophagic cell death and limits clonogenic survival. Mol. Cell 42(1), 23-35 (2011).

43. Li, X., He, S. \& Ma, B. Autophagy and autophagy-related proteins in cancer. Mol. Cancer 19(1), 12 (2020).

44. Shen, S. et al. Association and dissociation of autophagy, apoptosis and necrosis by systematic chemical study. Oncogene 30(45), 4544-4556 (2011).

45. Sosa, M. S. et al. Regulation of tumor cell dormancy by tissue microenvironments and autophagy. Adv. Exp. Med. Biol. 734, 73-89 (2013).

46. Badgwell, D. B. et al. The tumor-suppressor gene ARHI (DIRAS3) suppresses ovarian cancer cell migration through inhibition of the Stat 3 and FAK/Rho signaling pathways. Oncogene 31(1), 68-79 (2012).

47. Gundara, J. S. et al. Oncophagy: Harnessing regulation of autophagy in cancer therapy. Endocr. Relat. Cancer 19(6), R281-R295 (2012).

48. Tebbe, M. et al. Colloidally stable and surfactant-free protein-coated gold nanorods in biological media. ACS Appl. Mater. Interfaces 7(10), 5984-5991 (2015).

49. Qiu, Y. et al. Surface chemistry and aspect ratio mediated cellular uptake of Au nanorods. Biomaterials 31(30), 7606-7619 (2010).

50. Chaves, C. F. et al. Genes related to maintenance of autophagy and successful aging. Arq. Neuropsiquiatr. 76(12), 831-839 (2018).

51. Flynn, A. L. B. et al. Autophagy inhibition elicits emergence from metastatic dormancy by inducing and stabilizing Pfkfb3 expression. Nat. Commun. 10(1), 1-15 (2019).

52. Andaloussi, A. E. et al. Defective expression of ATG4D abrogates autophagy and promotes growth in human uterine fibroids. Cell Death Discov. 3(1), 17041 (2017).

53. Galluzzi, L. et al. Pharmacological modulation of autophagy: Therapeutic potential and persisting obstacles. Nat. Rev. Drug Discov. 16(7), 487 (2017).

54. Broz, D. K. et al. Global genomic profiling reveals an extensive p53-regulated autophagy program contributing to key p53 responses. Genes Dev. 27(9), 1016-1031 (2013).

55. Liang, C. et al. Autophagic and tumour suppressor activity of a novel Beclin1-binding protein UVRAG. Nat. Cell Biol. 8(7), 688-698 (2006)

56. Maes, H. et al. Tumor vessel normalization by chloroquine independent of autophagy. Cancer Cell 26(2), 190-206 (2014).

57. Liu, Y. et al. STAT3/p53 pathway activation disrupts IFN- $\beta$-induced dormancy in tumor-repopulating cells. J. Clin. Investig. 128(3), 1057-1073 (2018).

58. Cubillos-Ruiz, J. R., Bettigole, S. E. \& Glimcher, L. H. Tumorigenic and immunosuppressive effects of endoplasmic reticulum stress in cancer. Cell 168(4), 692-706 (2017).

59. Attar-Schneider, O., Drucker, L. \& Gottfried, M. Migration and epithelial-to-mesenchymal transition of lung cancer can be targeted via translation initiation factors eIF4E and eIF4GI. Lab. Investig. 96(9), 1004-1015 (2016).

60. Xie, W. et al. Chaperone-mediated autophagy prevents apoptosis by degrading BBC3/PUMA. Autophagy 11(9), 1623-1635 (2015).

61. Aqbi, H. F. et al. IFN- $\gamma$ orchestrates tumor elimination, tumor dormancy, tumor escape, and progression. J. Leukoc. Biol. 103(6), 1219-1223 (2018).

62. Cianfanelli, V. et al. AMBRA1 links autophagy to cell proliferation and tumorigenesis by promoting c-Myc dephosphorylation and degradation. Nature Cell Biology. 17(1), 20-30. https://doi.org/10.1038/ncb3072 (2015).

63. Chen, S. et al. The residual tumor autophagy marker LC3B serves as a prognostic marker in local advanced breast cancer after neoadjuvant chemotherapy. Clin. Cancer Res. 19(24), 6853-6862 (2013).

64. Kang, M. R. et al. Frameshift mutations of autophagy-related genes ATG2B, ATG5, ATG9B and ATG12 in gastric and colorectal cancers with microsatellite instability. J. Pathol. 217(5), 702-706 (2009). 
65. Tong, L. et al. Tumour cell dormancy as a contributor to the reduced survival of GBM patients who received standard therapy. Oncol. Rep. 40(1), 463-471 (2018).

66. Lamparska-Przybysz, M., Gajkowska, B. \& Motyl, T. BID-deficient breast cancer MCF-7 cells as a model for the study of autophagy in cancer therapy. Autophagy 2(1), 47-48 (2006).

67. Hu, X. et al. CXCR4-mediated signaling regulates autophagy and influences acute myeloid leukemia cell survival and drug resistance. Cancer Lett. 425, 1-12 (2018).

68. He, L. et al. Fas-associated protein with death domain (FADD) regulates autophagy through promoting the expression of Ras homolog enriched in brain (Rheb) in human breast adenocarcinoma cells. Oncotarget 7(17), 24572 (2016).

69. Pyo, J.-O. et al. Essential roles of Atg 5 and FADD in autophagic cell death dissection of autophagic cell death into vacuole formation and cell death. J. Biol. Chem. 280(21), 20722-20729 (2005).

70. Best, K. T. et al. Deletion of NFKB1 enhances canonical NF- $\mathrm{kB}$ signaling and increases macrophage and myofibroblast content during tendon healing. Sci. Rep. 9(1), 1-11 (2019).

71. Zhu, X. et al. NF-kB pathway link with ER stress-induced autophagy and apoptosis in cervical tumor cells. Cell Death Discov. 3(1), 1-8 (2017).

72. Trocoli, A. \& Djavaheri-Mergny, M. The complex interplay between autophagy and NF- $\mathrm{kB}$ signaling pathways in cancer cells. Am. J. Cancer Res. 1(5), 629 (2011).

73. Poehler, A.-M. et al. Autophagy modulates SNCA/ $\alpha$-synuclein release, thereby generating a hostile microenvironment. Autophagy 10(12), 2171-2192 (2014).

74. Song, J.-X. et al. HMGB1 is involved in autophagy inhibition caused by SNCA/ $\alpha$-synuclein overexpression: A process modulated by the natural autophagy inducer corynoxine B. Autophagy 10(1), 144-154 (2014).

75. Chen, S. et al. Salidroside protects SH-SY5Y from pathogenic $\alpha$-synuclein by promoting cell autophagy via mediation of mTOR/ p70S6K signaling. Mol. Med. Rep. 20(1), 529-538 (2019).

76. Yeo, S. Y. et al. Transglutaminase 2 contributes to a TP53-induced autophagy program to prevent oncogenic transformation. Elife 5, e07101 (2016).

77. Nagata, T. et al. Hepatocyte growth factor regulated tyrosine kinase substrate in the peripheral development and function of B-cells. Biochem. Biophys. Res. Commun. 443(2), 351-356 (2014).

78. Sun, Y. et al. A novel TP53 pathway influences the HGS-mediated exosome formation in colorectal cancer. Sci. Rep. 6, 28083 (2016).

79. Maruyama, T. \& Noda, N. N. Autophagy-regulating protease Atg4: structure, function, regulation and inhibition. J. Antibiot. 71(1), 72-78 (2018).

80. Fernández, Á. F. \& López-Otín, C. The functional and pathologic relevance of autophagy proteases. J. Clin. Investig. 125(1), 33-41 (2015).

81. Cusan, M. et al. Landscape of CDKN1B mutations in luminal breast cancer and other hormone-driven human tumors. Front. Endocrinol. 9, 393-393 (2018).

82. La Belle Flynn, A. et al. Autophagy inhibition elicits emergence from metastatic dormancy by inducing and stabilizing Pfkfb3 expression. Nat. Commun. 10(1), 3668 (2019).

83. Aqbi, H. F. et al. IFN- $\gamma$ orchestrates tumor elimination, tumor dormancy, tumor escape, and progression. J. Leukoc. Biol. https:// doi.org/10.1002/JLB.5MIR0917-351R (2018).

84. Sun, W. L. et al. Ambra1 modulates the sensitivity of breast cancer cells to epirubicin by regulating autophagy via ATG12. Cancer Sci. 109(10), 3129-3138 (2018).

85. Sun, W. L. Ambra1 in autophagy and apoptosis: Implications for cell survival and chemotherapy resistance (Review). Oncol. Lett. 12(1), 367-374 (2016).

86. Wang, N. et al. Atg9b deficiency suppresses autophagy and potentiates endoplasmic reticulum stress-associated hepatocyte apoptosis in hepatocarcinogenesis. Theranostics 7(8), 2325-2338 (2017).

87. Hervouet, E. et al. The autophagy GABARAPL1 gene is epigenetically regulated in breast cancer models. BMC Cancer 15, 729 (2015).

88. Jo, Y. K. et al. Increased expression of ATG10 in colorectal cancer is associated with lymphovascular invasion and lymph node metastasis. PLoS One 7(12), e52705 (2012).

89. Vasiljeva, O. et al. Tumor cell-derived and macrophage-derived cathepsin B promotes progression and lung metastasis of mammary cancer. Cancer Res. 66(10), 5242 (2006).

90. Chen, Z., Teo, A. E. \& McCarty, N. ROS-induced CXCR4 signaling regulates mantle cell lymphoma (MCL) cell survival and drug resistance in the bone marrow microenvironment via autophagy. Clin. Cancer Res. 22(1), 187-199 (2016).

91. Wang, S. \& Gu, K. Insulin-like growth factor 1 inhibits autophagy of human colorectal carcinoma drug-resistant cells via the protein kinase B/mammalian target of rapamycin signaling pathway. Mol. Med. Rep. 17(2), 2952-2956 (2018).

92. Sipos, F. et al. Relation of the IGF/IGF1R system to autophagy in colitis and colorectal cancer. World J. Gastroenterol. 23(46), 8109-8119 (2017).

93. Liu, M. et al. INS-gene mutations: from genetics and beta cell biology to clinical disease. Mol. Aspects Med. 42, 3-18 (2015).

94. Zheng, L.-Q., Li, S.-Y. \& Li, C.-X. Expression profiling analysis of autophagy-related genes in perineural invasion of cutaneous squamous cell carcinoma. Oncol. Lett. 15(4), 4837-4848 (2018).

95. Yu, X., Long, Y. C. \& Shen, H.-M. Differential regulatory functions of three classes of phosphatidylinositol and phosphoinositide 3-kinases in autophagy. Autophagy 11(10), 1711-1728 (2015).

96. Liu, J. et al. Knockdown of MAPK14 inhibits the proliferation and migration of clear cell renal cell carcinoma by downregulating the expression of CDC25B. Cancer Med. 9(3), 1183-1195 (2020).

97. Mesquita, F. P. et al. MAPK14 (p38a) inhibition effects against metastatic gastric cancer cells: A potential biomarker and pharmacological target. Toxicol. In Vitro 66, 104839 (2020).

98. Xiong, Y. et al. ARG2 impairs endothelial autophagy through regulation of MTOR and PRKAA/AMPK signaling in advanced atherosclerosis. Autophagy 10(12), 2223-2238 (2014).

99. O'Prey, J. et al. Analysis of DRAM-related proteins reveals evolutionarily conserved and divergent roles in the control of autophagy. Cell Cycle 8(14), 2260-2265 (2009).

100. Wudu, M. et al. DRAM2 acts as an oncogene in non-small cell lung cancer and suppresses the expression of p53. J. Exp. Clin. Cancer Res. 38(1), 72-72 (2019).

101. Chen, H. et al. UBL4A inhibits autophagy-mediated proliferation and metastasis of pancreatic ductal adenocarcinoma via targeting LAMP1. J. Exp. Clin. Cancer Res. 38(1), 297 (2019).

102. Okato, A. et al. Direct regulation of LAMP1 by tumor-suppressive microRNA-320a in prostate cancer. Int. J. Oncol. 49(1), 111-122 (2016)

103. mTOR activates a metastatic translational program. Cancer Discov. 2(4), 297 (2012).

104. Artero-Castro, A. et al. Disruption of the ribosomal P complex leads to stress-induced autophagy. Autophagy 11(9), 1499-1519 (2015).

105. Xiong, X. et al. Ribosomal protein S27-like regulates autophagy via the $\beta$-TrCP-DEPTOR-mTORC1 axis. Cell Death Dis. 9(11), 1131 (2018). 
106. Yang, Y. et al. Cathepsin S mediates gastric cancer cell migration and invasion via a putative network of metastasis-associated proteins. J. Proteome Res. 9(9), 4767-4778 (2010).

107. Gormley, J. A. et al. The role of Cathepsin $\mathrm{S}$ as a marker of prognosis and predictor of chemotherapy benefit in adjuvant CRC: A pilot study. Br. J. Cancer 105(10), 1487-1494 (2011).

108. Leal, M. F. et al. Early enrichment of ESR1 mutations and the impact on gene expression in presurgical primary breast cancer treated with aromatase inhibitors. Clin. Cancer Res. 25(24), 7485-7496 (2019).

109. Paolillo, C. et al. Detection of activating estrogen receptor gene (ESR1) mutations in single circulating tumor cells. Clin. Cancer Res. 23(20), 6086 (2017).

110. Liu, Y., Lv, J. \& Huang, B. Mediating the death of dormant tumor cells. Mol. Cell. Oncol. 5(4), el458013 (2018).

111. Su, Z. et al. Apoptosis, autophagy, necroptosis, and cancer metastasis. Mol. Cancer 14, 48 (2015).

112. Vera-Ramirez, L. et al. Autophagy promotes the survival of dormant breast cancer cells and metastatic tumour recurrence. Nat. Commun. 9(1), 1944 (2018).

113. Wang, L. et al. TMEM166, a novel transmembrane protein, regulates cell autophagy and apoptosis. Apoptosis 12(8), 1489-1502 (2007).

114. Cheng, H. et al. Overexpression of Ulk2 inhibits proliferation and enhances chemosensitivity to cisplatin in non-small cell lung cancer. Oncol. Lett. 17(1), 79-86 (2019).

115. King, K. Y. et al. Irgm1 protects hematopoietic stem cells by negative regulation of IFN signaling. Blood 118(6), 1525-1533 (2011).

116. Bai, H. et al. A transcriptional variant of the LC3A gene is involved in autophagy and frequently inactivated in human cancers. Oncogene 31(40), 4397-4408 (2012).

117. Dunwell, T. et al. A genome-wide screen identifies frequently methylated genes in haematological and epithelial cancers. Mol. Cancer 9, 44 (2010).

118. Aqbi, H. F. et al. Autophagy-deficient breast cancer shows early tumor recurrence and escape from dormancy. Oncotarget 9(31), 22113-22122 (2018)

119. Karch, J. et al. Autophagic cell death is dependent on lysosomal membrane permeability through Bax and Bak. Elife 6, e30543 (2017).

120. Lindqvist, L. M. \& Vaux, D. L. BCL2 and related prosurvival proteins require BAK1 and BAX to affect autophagy. Autophagy 10(8), 1474-1475 (2014)

121. Lamparska-Przybysz, M., Gajkowska, B. \& Motyl, T. Cathepsins and BID are involved in the molecular switch between apoptosis and autophagy in breast cancer MCF-7 cells exposed to camptothecin. J. Physiol. Pharmacol. 56(Suppl 3), 159-179 (2005).

122. Chen, C.-Y. et al. PTEN: Tumor suppressor and metabolic regulator. Front. Endocrinol. 9, 338 (2018).

123. Yamahara, K. et al. The role of autophagy in the pathogenesis of diabetic nephropathy. J. Diabetes Res. 2013, 193757 (2013).

124. O'Prey, J. et al. Analysis of DRAM-related proteins reveals evolutionarily conserved and divergent roles in the control of autophagy. Cell Cycle 8(14), 2260-2265 (2009).

\section{Acknowledgements}

This work is a part of M.Sc. thesis of Maryam Ghafarkhani in medical nanotechnology at Tabriz University of Medical Sciences (TBZMED).

\section{Author contributions}

(1) A.Z. and F.B. apprehended of the presented idea. A.Z. settled the theory and performed the analysis, discussion, and supervised the findings of this work. (2) M.G. MSc student and contributed in data gathering and investigation about idea. (3) R.R. contributed to the scientific writing, data mining, and interpretation of the results. (4) C.B.A. fully supported PCR array and its data gathering and interpretation. (5) M.S. support us for PTT instrumental and data gathering. (6) A.K. contributed in mRNA extraction and cDNA synthesis.

\section{Funding}

The current work was fully supported by Tabriz University of Medical Sciences. (Grant number: 58854).

\section{Competing interests}

The authors declare no competing interests.

\section{Additional information}

Supplementary Information The online version contains supplementary material available at https://doi.org/ 10.1038/s41598-021-02697-y.

Correspondence and requests for materials should be addressed to A.Z. or F.B.

Reprints and permissions information is available at www.nature.com/reprints.

Publisher's note Springer Nature remains neutral with regard to jurisdictional claims in published maps and institutional affiliations.

(c) (i) Open Access This article is licensed under a Creative Commons Attribution 4.0 International License, which permits use, sharing, adaptation, distribution and reproduction in any medium or format, as long as you give appropriate credit to the original author(s) and the source, provide a link to the Creative Commons licence, and indicate if changes were made. The images or other third party material in this article are included in the article's Creative Commons licence, unless indicated otherwise in a credit line to the material. If material is not included in the article's Creative Commons licence and your intended use is not permitted by statutory regulation or exceeds the permitted use, you will need to obtain permission directly from the copyright holder. To view a copy of this licence, visit http://creativecommons.org/licenses/by/4.0/.

(C) The Author(s) 2021 